\title{
Impact of upstream moisture structure on a back-building convective precipitation system in south-eastern France during HyMeX IOP13
}

\author{
Keun-Ok Lee ${ }^{1}$, Cyrille Flamant ${ }^{2}$, Fanny Duffourg ${ }^{3}$, Véronique Ducrocq ${ }^{3}$, and Jean-Pierre Chaboureau ${ }^{1}$ \\ ${ }^{1}$ Laboratoire d'Aérologie, Université de Toulouse, CNRS, UPS, Toulouse, France \\ ${ }^{2}$ LATMOS/IPSL, CNRS, Sorbonne Université and Université Paris-Saclay, Paris, France \\ ${ }^{3}$ CNRM, Université de Toulouse, Météo-France \& CNRS, UMR3589, Toulouse, France
}

Correspondence: Keun-Ok Lee (keun-ok.lee@aero.obs-mip.fr)

Received: 11 July 2018 - Discussion started: 23 July 2018

Revised: 19 November 2018 - Accepted: 20 November 2018 - Published: 29 November 2018

\begin{abstract}
The present study examines the impact of the environmental moisture structure in the lower troposphere (below $2 \mathrm{~km}$ above sea level, a.s.l.) on the precipitation development, observed in southern France during Intensive Observation Period (IOP) 13 of the first Special Observation Period of the Hydrological cycle in the Mediterranean Experiment (HyMeX SOP-1), through a series of sensitivity experiments using the non-hydrostatic mesoscale atmospheric numerical model (Meso-NH). The control simulation (CNTL) and all the other 12 sensitivity experiments examined in this study succeed in reproducing a heavy precipitation event (HPE) in the coastal mountainous region of Var in south-eastern France as observed. The sensitivity experiments are designed to investigate the response of the HPE to the variability of the water vapour content upstream in the moist marine atmospheric boundary layer (MABL) and the drier air above. The comparisons between CNTL and the 12 sensitivity experiments show how the life cycle of precipitation associated with the HPE, but also the upstream flow (over the sea), is modified, even for moisture content changes of only $1 \mathrm{~g} \mathrm{~kg}^{-1}$ below $2 \mathrm{~km}$ a.s.l. Within the low-level wind convergence between southerlies and south-westerlies, a small increase of moisture content in the MABL prolongs moderate precipitation ( $\geq 5 \mathrm{~mm}$ in $15 \mathrm{~min}$ ) and enlarges the area of weak precipitation ( $\geq 1 \mathrm{~mm}$ in $15 \mathrm{~min}$ ). The moistening in the $1-$ $2 \mathrm{~km}$ a.s.l. layer, just above the MABL, prolongs the duration of moderate precipitation, for a similar total precipitation amount as in CNTL. The drier MABL and 1-2 km a.s.1. layer shorten the lifetime of precipitation and reduce the total precipitation amount with respect to CNTL. We also found
\end{abstract}

that the moisture in the MABL has a stronger impact on producing enhanced precipitation (both in terms of amount and intensity) than the moisture just above (1-2 km a.s.1.). Also, it is worth noting that adding moisture in the MABL does not necessarily lead to enhanced precipitation amount. In moistening the MABL, the duration of moderate precipitation increases with increasing moisture as does the area covered by weak precipitation, while the area covered by the intense precipitation $(\geq 30 \mathrm{~mm})$ decreases. Despite a simplified moisture-profile modification approach, this study suggests that moisture structure in the lower troposphere is key for accurate prediction at short-term range of the timing and location of precipitation in the coastal mountainous region in southern France.

\section{Introduction}

Most of the Mediterranean countries face heavy precipitation events (HPEs), especially during autumn. More than $100 \mathrm{~mm}$ of precipitation in less than $6 \mathrm{~h}$ is not uncommon in these regions, and such rainfall accumulations often cause flash floods with large material damages and important human losses. These high-impact events are most often due to the quasi-stationary mesoscale convective system (MCS) (e.g. Nuissier et al., 2008; Romero et al., 1999; Trapero et al., 2013a, b; Barthlott and Davolio, 2015). 
During the autumn, the warm Mediterranean is a significant source of moistening and heating for the marine atmospheric boundary layer (MABL) through latent and sensible heat fluxes (Duffourg and Ducrocq, 2011). The southerly low-level marine winds that prevail during HPEs over the north-western Mediterranean transport this moist and conditionally unstable air toward the coastal mountainous region (Ricard et al., 2012). Such low-level conditions are favoured by typical synoptic patterns. Nuissier et al. (2011) found that the synoptic-scale pattern propitious to HPEs over the French Mediterranean region consists of an upper-level trough located west of France and an upper-level ridge over central Europe. MCSs preferably develop eastward of a slowevolving disturbance associated with an upper-level trough and leading a south-westerly diffluent flow. Such a synoptic pattern favours a persistent low-level moist and conditionally unstable marine flow directed towards the costal mountainous regions.

When this conditionally unstable low-level flow impinges on some of the mountain range foothills that border the western Mediterranean, a back-building MCS can be triggered and renewed repeatedly at the same location, as long as the same low-level and upper-level conditions persist. Orographic lifting has been largely proposed in past studies as a mechanism for triggering HPEs over the western Mediterranean (e.g. Buzzi et al., 1998; Houze, 1993; Jansa et al., 2001; Lin, 1993; Romero et al., 2015; Rotunno and Ferretti, 2001; Smith, 1979; Trapero et al., 2013a, b; Miglietta and Rotunno, 2014). Furthermore, a low-level cold pool forming under a MCS can also lift the impinging ambient lowlevel flow at its leading edge (Ducrocq et al., 2008) or modify the low-level circulation locally and enhance convergence areas (Duffourg et al., 2016). Furthermore, other convectiontriggering mechanisms, stemming from the low-level marine flows interaction with the complex terrain of the western Mediterranean, have been highlighted (e.g. Ducrocq et al., 2016). The dynamical and thermodynamical characteristics of the low-level flows are decisive with respect to the triggering mechanisms involved (Bresson et al., 2012).

The water vapour transported by the marine flow is a crucial ingredient of Mediterranean HPEs. Therefore, the realistic representation of its spatiotemporal variability in numerical weather prediction models is critical for HPE forecast. Predicting the initiation of convection in cloud resolving models can also be highly dependent on very accurate estimates of water vapour within and just above the boundary layer (e.g. Crook, 1996; Ducrocq et al., 2002; Weckwerth et al., 2004; Bielli et al., 2012). This requires relevant moisture observations in the inflow region or within the convective storms, particularly over the sea. These are difficult to obtain on a regular basis in order to properly constrain numerical weather prediction models in terms of moisture.

The first Special Observation Period (SOP-1; Ducrocq et al., 2014) of the Hydrological cycle in the Mediterranean Experiment (HyMeX) took place in autumn 2012, aiming to improve our knowledge of the origin and transport pattern of moist air masses in pre-convective conditions and determine the link between these air masses and HPEs. During Intensive Observation Period 13 (IOP13, 14 October 2012) of HyMeX SOP-1, back-building MCSs developed in southeastern France shortly after 13:00 UTC (Duffourg et al., 2018). The synoptic situation of IOP13 is characterized by an upper-level trough associated with a surface disturbance situated over north-western France. Ahead of the associated cold front, a south-westerly low-level flow over the Mediterranean French coast brings a warm marine air mass inland. Thanks to aircraft water vapour measurement acquired over the Gulf of Lion (north-western Mediterranean) during IOP13, Duffourg et al. (2018) detailed the moisture structure upstream of the MCSs which was characterized by a moist conditionally unstable MABL (below $1 \mathrm{~km}$ above sea level, a.s.l.) topped by dry air masses just above (1-2 kma.s.l.). They emphasized the importance of the low-level moisture for feeding the convective systems observed during this HPE and the significance of the dry air above for strengthening the associated cold pools. The goal of the present study is to further investigate the impact of moist air in the boundary layer and surrounding dry air masses on the development and evolution of MCSs.

The impact of the environmental moisture structure on the development of a convective system (which produced $70 \mathrm{~mm}$ of precipitation in $6 \mathrm{~h}$ ), observed a few kilometres southwest offshore the Marseille and Var coastlines in southern France, is investigated here through a series of sensitivity experiments using the French non-hydrostatic mesoscale atmospheric numerical research model (Meso-NH) (Lac et al., 2018) at the horizontal grid spacing of $2.5 \mathrm{~km}$. The article is organized as follows: Sect. 2 describes the experimental design; the results of the control and sensitivity simulations are presented in Sects. 3 and 4, and then summarized in Sect. 5 with concluding remarks.

\section{Numerical simulation}

\subsection{Meso-NH model configuration}

Meso-NH (Lac et al., 2018), the mesoscale non-hydrostatic model, has already shown its capability to simulate HPEs in both real and idealized frameworks (Argence et al., 2008; Nuissier et al., 2008; Ducrocq et al., 2008; Clark and Chaboureau, 2010; Bresson et al., 2012). For this study, the same set-up as in Duffourg et al. (2016, 2018), that proved to be able to reproduce realistic convective systems, was used. It includes the same simulation domain over south-eastern France and the north-western Mediterranean $(200 \mathrm{~km} \times 200 \mathrm{~km}$ domain encompassing the precipitating systems and their marine low-level moisture-supplying flow; Fig. 1), the same horizontal grid spacing of $2.5 \mathrm{~km}$, the same vertical grid with 55 stretched vertical levels (Gal-Chen and 


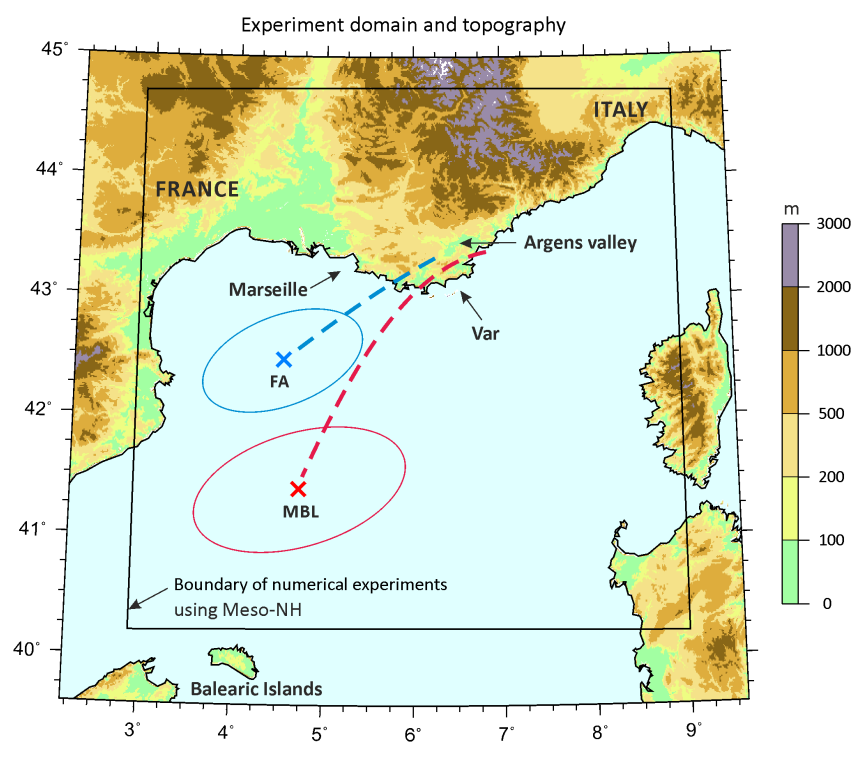

Figure 1. Topography and domain (black box) considered in numerical simulations using Meso-NH with a resolution of $2.5 \mathrm{~km}$. The centre location of the initial "sensitivity bubble" set in marine boundary layer (MBL) and free atmosphere (FA) experiments is depicted by red- and blue-coloured cross marks, respectively, while the horizontal range of the initial bubbles is marked by an ellipse-shaped solid line of the same colour. The red dashed line indicates the horizontal projection of backward trajectories of some air parcels taken in the upper part of the convective systems of the eastern Var coast, and the blue dashed line depicts the horizontal projection of backward trajectories of some air parcels taken in the cold pool generated by the convective systems over the eastern Var coast.

Somerville, 1975) up to $20 \mathrm{~km}$, and the same parameterization schemes: the bulk one-moment mixed microphysical scheme (Caniaux et al., 1994; Pinty and Jabouille, 1998) combining a three-class ice parameterization with a Kessler scheme for the warm processes, a 1-D turbulence parameterization based on a 1.5-order closure (Cuxart et al., 2000) of the turbulent kinetic energy equation with the Bougeault and Lacarrere (1989) mixing length, the Pergaud et al. (2009) eddy diffusivity mass flux scheme for shallow convection, the Rapid Radiation Transfer Model (Mlawer et al., 1997) for radiation, and the surface model SURFEX (Masson et al., 2013). The transport scheme for momentum variables is a weighted essentially non-oscillatory (WENO) scheme (Shu and Osher, 1988), while other variables are transported with the piecewise parabolic method (PPM) scheme (Colella and Woodward, 1984). An open wave radiation condition (Carpenter, 1982), combined with a five-grid-point relaxation flow scheme (Davies, 1976), is applied at the boundaries.

The control simulation (referred to as CNTL in the following) was initialized at 09:00 UTC on 14 October 2012. As in Duffourg et al. (2018), the initial and lateral boundary conditions are provided by the 3-hourly Application of Research to
Operational at Mesoscale - West Mediterranean (AROMEWMED) analyses (Fourrié et al., 2015). AROME-WMED is a dedicated version of the French operational convectionpermitting numerical prediction system AROME (Seity et al., 2011), set up specifically for the HyMeX field campaigns and covering the western Mediterranean.

\subsection{Control simulation}

During IOP13, convection initiation is observed around 12:00 UTC, over the sea, a few kilometres offshore the coast of south-eastern France. It develops into organized convective systems (not shown) in the surroundings of Marseille and along the coast of the Var region (geographical positions are given in Fig. 1). A maximum $6 \mathrm{~h}$ rainfall accumulation of $67 \mathrm{~mm}$ is recorded over land under the convective line anchored along the Var coast between 14:00 and 19:00 UTC on 14 October 2012. The CNTL simulation succeeds in reproducing heavy precipitation over south-eastern France. The CNTL simulation starts showing evidence of weak precipitation $(<5 \mathrm{~mm}$ per $15 \mathrm{~min})$ and low reflectivity (values than $30 \mathrm{dBZ}$ ) around 12:00 UTC over the sea (not shown). Then, the convection (highlighted by reflectivity values exceeding $45 \mathrm{dBZ}$; Lee et al., 2012) initiates upstream (yellow star; Fig. 2b), about $25 \mathrm{~km}$ further south than observed at 12:00 UTC, and maximum $15 \mathrm{~min}$ precipitation over $5 \mathrm{~mm}$ is simulated approximately $93 \mathrm{~km}$ from the initiation at 12:30 UTC (Fig. 2b). It develops preferably toward Marseille, then around the Argens valley region and the east coastal Var region (Figs. 2b and 3a, b), similarly as observed. The intense precipitation ( $\geq 15 \mathrm{~mm}$ per $15 \mathrm{~min}$, red circle in Fig. 2b) is first simulated at 14:00 UTC north of Marseille $\left(43.5^{\circ} \mathrm{N}, 5.6^{\circ} \mathrm{E}\right)$. The convective regions are simulated in the Argens valley region and the east coastal Var region from 14:00 to 16:00 UTC (Fig. 3b-d). The simulated amount of rainfall accumulation is realistic, with $74.2 \mathrm{~mm}$ in $6 \mathrm{~h}$ associated with the convective line over the eastern Var coast (longitude $6.5^{\circ}$ E; Fig. 2a).

Figure 4 displays the hourly evolution simulated by CNTL of the equivalent potential temperature, $\theta_{\mathrm{e}}$, at $925 \mathrm{hPa}$ and virtual potential temperature, $\theta_{\mathrm{v}}$, at the first model level (about $10 \mathrm{~m}$ ), together with the horizontal wind and the vertical velocity at $925 \mathrm{hPa}$ level during the period between 13:00 and 16:00 UTC. During this period, the marine warm and moist low-level air $\left(\theta_{\mathrm{e}}>322 \mathrm{~K}\right)$ progresses north-eastwards. At 13:00 UTC (Fig. 4a), it reaches the Var coast and convective ascents are localized along the coast on the mountainsides. From 14:00 UTC on (Fig. 4b-d), the cold air $\left(\theta_{\mathrm{v}}<291 \mathrm{~K}\right)$ formed by evaporative cooling under the intensifying precipitation spreads out over the plains (Figs. 3b-d and $2 \mathrm{~b}$ ). At 14:00 UTC, very high convective available potential energy (CAPE) values (i.e. in excess of $1590 \mathrm{~J} \mathrm{~kg}^{-1}$ ) are simulated around the Var coast in CNTL, in good agreement with the CAPE of $1600 \mathrm{~J} \mathrm{~kg}^{-1}$ derived from radiosounding measurements in Marseille at 15:00 UTC (not shown). The 

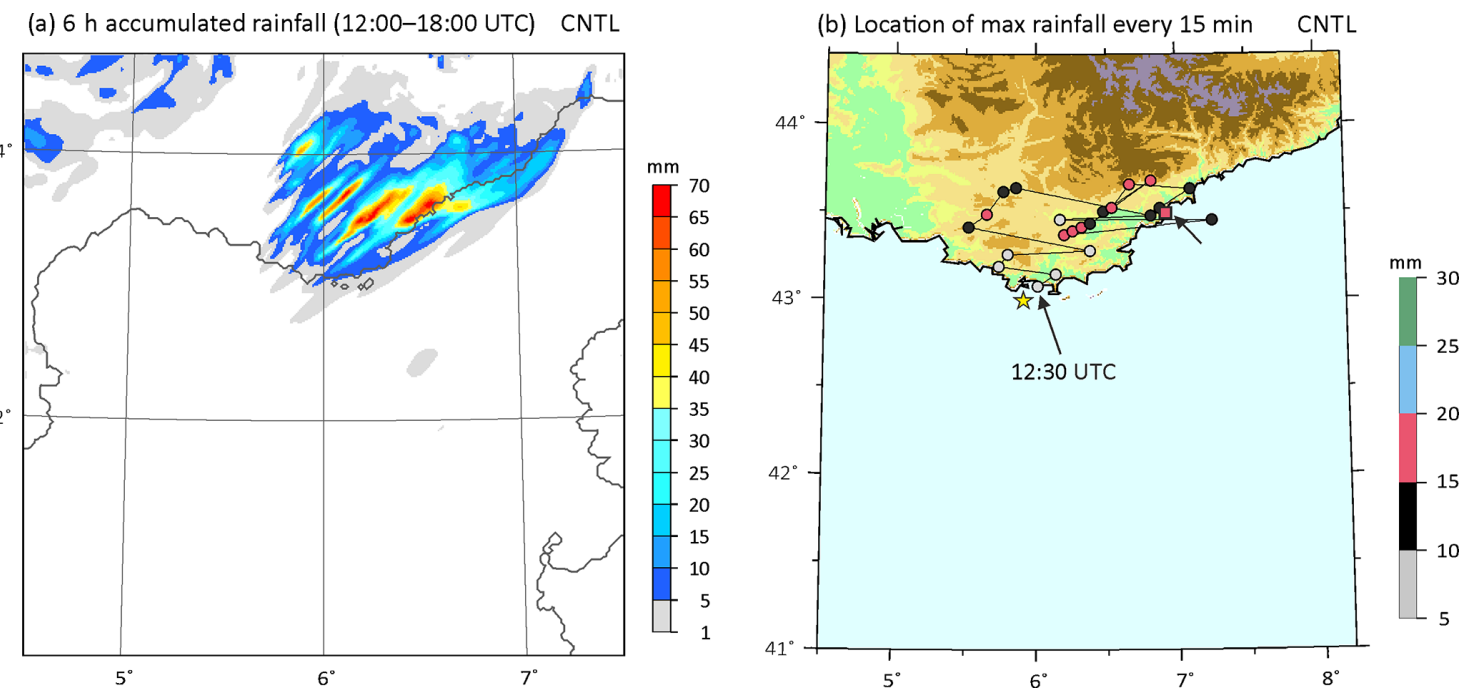

Figure 2. (a) The $6 \mathrm{~h}$ accumulated precipitation at 18:00 UTC and (b) evolution every 15 min between 12:00 and 18:00 UTC of the locations of maximum 15 min accumulated rainfall amount $\left(R_{\max }\right)$ simulated by the control run $(\mathrm{CNTL})$ on 14 October 2012. Also shown is the topography (see Fig. 1 for the scale). The location of first convection initiation (reflectivity over $45 \mathrm{dBZ}$ ) is marked by a yellow star, and the last precipitating point at 18:00 UTC is marked by a square with an arrow pointing to it in panel (b).
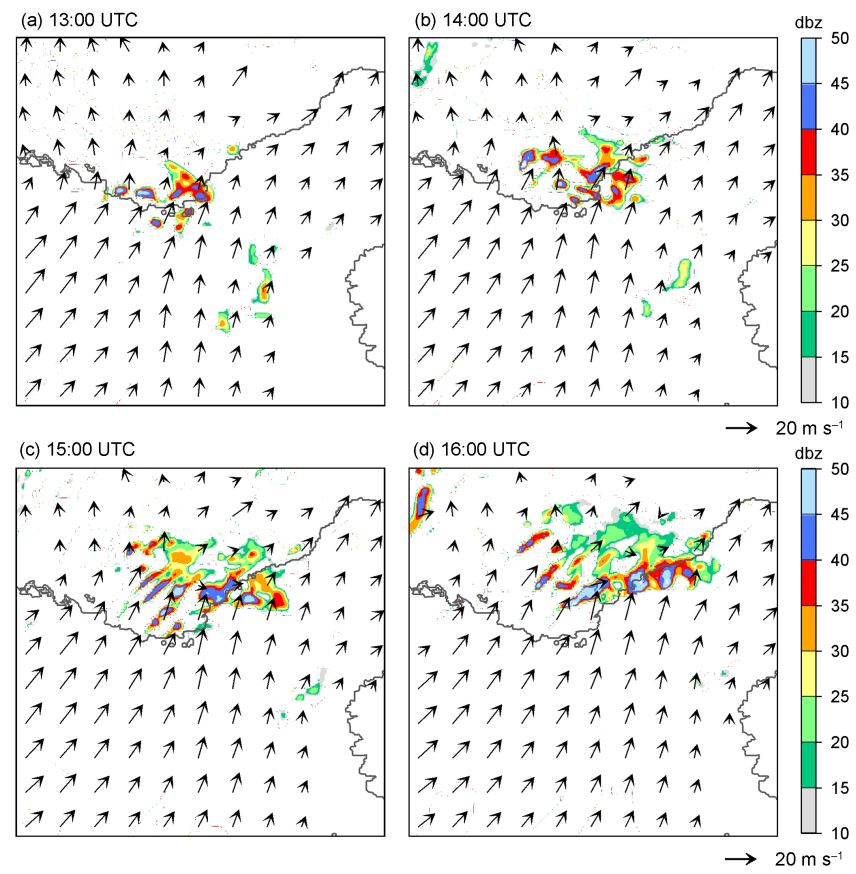

Figure 3. Radar reflectivity (dBZ) and horizontal winds simulated in CNTL at $2000 \mathrm{~m}$ a.s.1. at (a) 13:00, (b) 14:00, (c) 15:00, and (d) 16:00 UTC on 14 October 2012.

convection develops rapidly on the leading edge of the cold air channelled in the Argens valley (geophysical positions are given in Fig. 1) (Fig. 3c); then, it propagates to the eastern Var coast after 16:00 UTC (Fig. 3d). Convection is quasistationary along the eastern Var coastal region (Fig. 4d). The
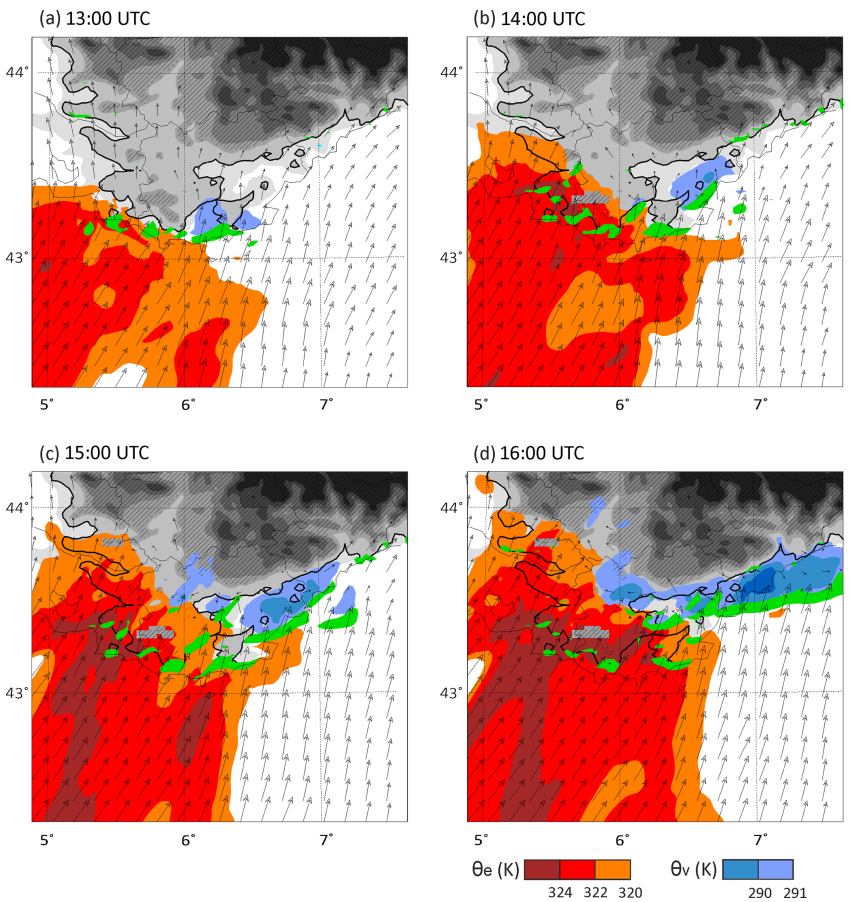

Figure 4. Equivalent potential temperature $\theta_{\mathrm{e}}$ at $925 \mathrm{hPa}(\mathrm{K}$, red areas), virtual potential temperature $\theta_{\mathrm{V}}$ at the first model level (K, blue areas below $291 \mathrm{~K}$ ), vertical motion at $500 \mathrm{~m}$ a.s.l. (green areas above $0.5 \mathrm{~m} \mathrm{~s}^{-1}$ ), and horizontal wind at $925 \mathrm{hPa}$ (arrows) simulated by CNTL at (a) 14:00, (b) 15:00, (c) 16:00, and (d) 17:00 UTC on 14 October 2012.

cold pool plays a major role in determining the location of the precipitation (Duffourg et al., 2018). 
To characterize the air mass supplying the precipitating system, backward trajectories of air parcels reaching the top of the simulated convective ascents are performed. They show that the convective ascents are fed by the southwesterly marine flow all similarly along the red dashed line drawn in Fig. 1. The vertical projection of the backward trajectories (not shown) provides evidence that the flow is confined to the lowest $1000 \mathrm{~m}$ above the sea surface before being lifted up to the top of the troposphere within $1 \mathrm{~h}$ in the convective ascents of the precipitating system. The low-level flow brings a moist (about $\left.10 \mathrm{~g} \mathrm{~kg}^{-1}\right)$ and warm $\left(\theta_{\mathrm{e}}\right.$ about $322 \mathrm{~K}$ ) air mass from the north-east of the Balearic Islands at 09:00 UTC to the south-eastern French coast, where it feeds the convective ascent. Another set of backward trajectories is computed to identify the air mass involved in the formation of the cold pool under the intense precipitation in the eastern Var coastal region. All trajectories follow a similar pathway, which is represented by a blue dashed line in Fig. 1. Moreover, the air mass involved in cold air pool formation comes mainly from a dry layer between 1 and $2 \mathrm{~km}$ a.s.l., just above the moist boundary layer, with water vapour mixing ratios (WVMRs) ranging between 3 and $8 \mathrm{~g} \mathrm{~kg}^{-1}$ (not shown).

The water vapour contents upstream of the HPE of IOP13 (over the sea; $41-42.5^{\circ} \mathrm{N}, 3.5-5.5^{\circ} \mathrm{E}$ ) at 06:00 UTC on 14 October 2012 of AROME-WMED analyses data are compared with that retrieved by the Special Sensor Microwave/Imager (SSM/I) at 06:25 UTC of the same day. The horizontal distribution of integrated water vapour (IWV) values between the AROME-WMED analyses and SSM/I over the north-western Mediterranean are in broad agreement, i.e. moister air to the north-east of the Balearic Islands and drier air offshore the south-west French coast (not shown) showing a mean IWV difference of $0.7 \mathrm{~kg} \mathrm{~m}^{-2}$, with averaged values of $18.2 \mathrm{~kg} \mathrm{~m}^{-2}$ in AROME-WMED analyses vs. $18.9 \mathrm{~kg} \mathrm{~m}^{-2}$ in SSM/I. In AROME-WMED analyses, near $90 \%$ of the IWV concentrates below $2 \mathrm{~km}$ a.s.l., i.e. $69.5 \%$ below $1 \mathrm{~km}$ a.s.l., $21 \%$ between 1 and $2 \mathrm{~km}$ a.s.l.

In the following, we will analyse the precipitating pattern and characteristics simulated over the Var coastal region and their sensitivity to the related upstream moisture environment by comparisons of results between CNTL and 12 sensitivity experiments with varying water vapour content in lower troposphere (below $2 \mathrm{~km}$ a.s.1.).

\subsection{Initial conditions of sensitivity experiments}

To study the sensitivity of IOP13 precipitation to the moisture structure in the low troposphere, two sets of experiments, in which the initial WVMR profiles are modified in the moist MABL (below $1 \mathrm{~km}$ a.s.l.) and in the dry layer above (1-2 km a.s.l.), are carried out, namely the marine boundary layer (MBL) and free atmosphere (FA) experiments, respectively (Table 1 and Figs. 1 and 5). The WVMR profiles are modified in the areas involved in the moisture supply of the precipitating system and in the cold pool formation. Then
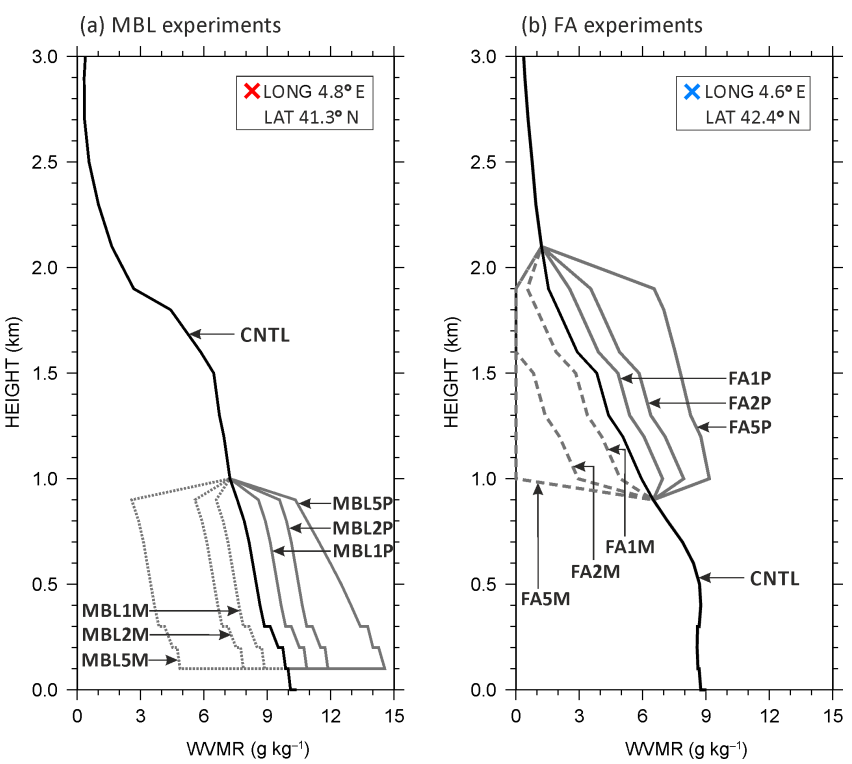

Figure 5. Vertical profiles of WVMR in the centre of the initial sensitivity bubble used in (a) MBL experiments and (b) FA experiments. Black solid lines are vertical profiles of the CNTL run at the same grid point as in MBL and FA. Solid grey lines represent experiments in which WVMR was augmented, while dashed grey lines represent experiments for which WVMR was reduced. The centre location of the initial sensitivity bubble used in MBL and FA is shown in Fig. 1.

the impact on the precipitation amount and location is analysed. The location and extent of the "sensitivity bubbles" are defined based on the results of backward trajectory analyses (red and blue dashed lines in Fig. 1) done using CNTL. For the six MBL experiments, the sensitivity bubble is located over the sea, centred about $230 \mathrm{~km}$ from the Marseille coastline (red-coloured cross in Fig. 1), with an ellipsoidal shape with a short axis of $80 \mathrm{~km}$ and a long axis of $160 \mathrm{~km}$ length (red ellipse in Fig. 1). Three MBL experiments were designed, with WVMR values between 100 and $1000 \mathrm{~m}$ a.s.l. in the sensitivity bubble being increased by 1,2 , and $5 \mathrm{~g} \mathrm{~kg}^{-1}$ up to the saturation limit (Fig. 5a and Table 1a). In other words, the water vapour value at saturation with respect to liquid water was calculated at each altitude and used as an upper threshold of the modified WVMR. The sensitivity bubbles are referred to as the MBL1P, MBL2P, and MBL5P experiments, respectively, in the following. Likewise, three MBL experiments were designed with WVMR values between 100 and $1000 \mathrm{ma}$ a.s.l. in the sensitivity bubble being decreased by 1,2 , and $5 \mathrm{~g} \mathrm{~kg}^{-1}$ (MBL1M, MBL2M, and MBL5M, respectively; see Fig. 5a).

For the six FA experiments (Table 1b), the sensitivity bubble is centred at about $150 \mathrm{~km}$ from the Marseille coastline (blue-coloured cross in Fig. 1) and has an ellipsoidal shape with a short axis of $60 \mathrm{~km}$ and a long axis of $120 \mathrm{~km}$ length (blue ellipse in Fig. 1). In these experiments, the WVMR 
Table 1. List of sensitivity experiment and WVMR modifications with respect to the control simulation (CNTL).

\begin{tabular}{|c|c|c|c|c|c|c|}
\hline (a) Exp. & MBL1M & MBL2M & MBL5M & MBL1P & MBL2P & MBL5P \\
\hline $\begin{array}{l}\text { Max WVMR } \\
\text { difference }\end{array}$ & $+1 \mathrm{~g} \mathrm{~kg}^{-1}$ & $+2 \mathrm{~g} \mathrm{~kg}^{-1}$ & $+5 \mathrm{~g} \mathrm{~kg}^{-1}$ & $+1 \mathrm{~g} \mathrm{~kg}^{-1}$ & $+2 \mathrm{~g} \mathrm{~kg}^{-1}$ & $+5 \mathrm{~g} \mathrm{~kg}^{-1}$ \\
\hline $\begin{array}{l}\text { Altitudes } \\
\text { modified }\end{array}$ & \multicolumn{6}{|c|}{0.1 to $1 \mathrm{~km}$ above sea level } \\
\hline (b) Exp. & FA1M & FA2M & FA5M & FA1P & FA2P & FA5P \\
\hline $\begin{array}{l}\text { Max WVMR } \\
\text { difference }\end{array}$ & $+1 \mathrm{~g} \mathrm{~kg}^{-1}$ & $+2 \mathrm{~g} \mathrm{~kg}^{-1}$ & $+5 \mathrm{~g} \mathrm{~kg}^{-1}$ & $+1 \mathrm{~g} \mathrm{~kg}^{-1}$ & $+2 \mathrm{~g} \mathrm{~kg}^{-1}$ & $+5 \mathrm{~g} \mathrm{~kg}^{-1}$ \\
\hline $\begin{array}{l}\text { Altitudes } \\
\text { modified }\end{array}$ & \multicolumn{6}{|c|}{1 to $2 \mathrm{~km}$ above sea level } \\
\hline
\end{tabular}

values between 1000 and $2000 \mathrm{~m}$ a.s.l. in the sensitivity bubble are increased (decreased) by 1, 2, and $5 \mathrm{~g} \mathrm{~kg}^{-1}$ (Fig. 5b), keeping the minimum WVMR value at $0 \mathrm{~g} \mathrm{~kg}^{-1}$, and they are referred to as the FA1P (FA1M), FA2P (FA2M), and FA5P (FA5M) experiments, respectively. For FA2M and FA5M, the bottom threshold of $0 \mathrm{~g} \mathrm{~kg}^{-1}$ is used for reformulating the WVMR profiles. Other environmental conditions in the MBL and FA experiments are the same as in CNTL. Using backward trajectory analysis, we can assess that the origins of air parcels feeding the convective system and of air parcels feeding the cold pools are within the sensitivity bubbles of the FA and MBL experiments, respectively (ellipsoids in Fig. 1), and that the trajectories do not deviate significantly from one experiment to the next, even though some differences exist.

The magnitude of the WVMR anomalies introduced in the sensitivity bubbles are based on recent studies which confronted the quality of the AROME-WMED analyses in the lower troposphere with WVMR profiling instruments operating over the Mediterranean, in particular using groundbased and airborne water vapour lidars (e.g. Chazette et al., 2016; Lee et al., 2016, 2017). Chazette et al. (2016) evidenced that the root mean square error between AROME and lidar WVMRs in the vicinity of the Balearic Islands below $2 \mathrm{~km}$ a.s.l. ranges between 1 and $1.6 \mathrm{~g} \mathrm{~kg}^{-1}$, while Lee et al. (2016) and Lee et al. (2017) highlighted differences as large as $3-4 \mathrm{~g} \mathrm{~kg}^{-1}$ in the MABL upstream of MCSs over the Tyrrhenian Sea and the Balearic Sea, respectively. In this study, experiments with \pm 1 and $2 \mathrm{~g} \mathrm{~kg}^{-1}$ were conducted to understand the impact of water vapour uncertainty in the vicinity of the Balearic Islands on precipitation downstream, while the experiments with $\pm 5 \mathrm{~g} \mathrm{~kg}^{-1}$ are done to see such an impact in a more extreme environment.

To investigate the WVMR impact on the location, intensity and duration of precipitation, we consider several indicators, such as (1) the maximum of the $6 \mathrm{~h}$ accumulated precipitation amount $\left(\mathrm{RR}_{\max }\right)$, the domain-averaged total sum of the $6 \mathrm{~h}$ rainfall accumulation $\left(\mathrm{RR}_{\text {sum }}\right)$, and the $\mathrm{RR}_{\text {sum }}$ produced over land $\left(R_{\text {land }}\right)$ and over the sea $\left(R_{\text {sea }}\right)$ in the fixed area $\left(40.5-45^{\circ} \mathrm{N}, 3.5-9^{\circ} \mathrm{E}\right)$ from 12:00 UTC on 14 October 2012 to understand the impact of WVMR variability on precipitation amount, (2) the horizontal area $\left(\mathrm{km}^{2}\right)$ of $6 \mathrm{~h}$ precipitation $\geq 1 \mathrm{~mm}\left(\mathrm{AR}_{01}\right)$ and $\geq 30 \mathrm{~mm}\left(\mathrm{AR}_{30}\right)$ in CNTL, and its deviation (\%) from those in the MBL and FA experiments, and (3) the duration of precipitation ( $\geq 5 \mathrm{~mm}$ ) over the land $\left(D_{\text {land }}\right)$, duration of precipitation $\geq 5 \mathrm{~mm}$ per $15 \mathrm{~min}$ ( $\left.D_{\mathrm{RR} 05}\right)$, and duration of precipitation $\geq 15 \mathrm{~mm}$ per $15 \mathrm{~min}$ $\left(D_{\mathrm{RR} 15}\right)$. Those indicators are presented in Figs. 6 and 12 for the different sensitivity experiments (MBL and FA, respectively). Figure 7 displays the $6 \mathrm{~h}$ rainfall accumulation simulated in the MBL sensitivity experiments, and Fig. 8 show the evolution of the maximum accumulated precipitation amount $\left(\mathrm{RR}_{\max }\right)$ every $15 \mathrm{~min}$ during $6 \mathrm{~h}$, highlighting the differences in time, intensity, and location of the precipitation. Figure 9 shows the temporal evolution of the maximum of CAPE in the sensitivity bubble every 15 min from 09:30 to 14:45 UTC in CNTL, MBL $\times$ M (i.e. MBL1M, MBL2M, and MBL5M), and $\mathrm{MBL} \times \mathrm{P}$ (i.e. MBL1P, MBL2P, and MBL5P). Figures 13 and 14 show the same parameters as Figs. 7 and 8 , respectively, but for FA experiments. Note that the weak precipitation amounts (i.e. less than $5 \mathrm{~mm}$ per $15 \mathrm{~min}$ ) are not displayed in Figs. 8 and 14 to focus on active convective system. Also, note that the analysis of the precipitation characteristics is conducted for $6 \mathrm{~h}$ (from 12:00 to 18:00 UTC) when the convective systems affect the inland and coastal regions. Precipitation continues over the sea after 18:00 UTC in all experiments, as observed.

\section{Sensitivity to moisture in the marine boundary layer (MBL experiments)}

\subsection{Dried marine boundary layer}

Decreasing the moisture contents in the MABL in MBL2M and MBL5M leads to less precipitation with both decreasing $R_{\text {max }}$ and $R R_{\text {sum }}$ from CNTL to $M B L \times M$ (grey and white bars in Fig. 6a), while the maximum precipitation accumulation remains similar in MBL1M with $75.7 \mathrm{~mm}$. The reduction of total precipitation seen over land $\left(\mathrm{RR}_{\text {land }}\right.$, be- 

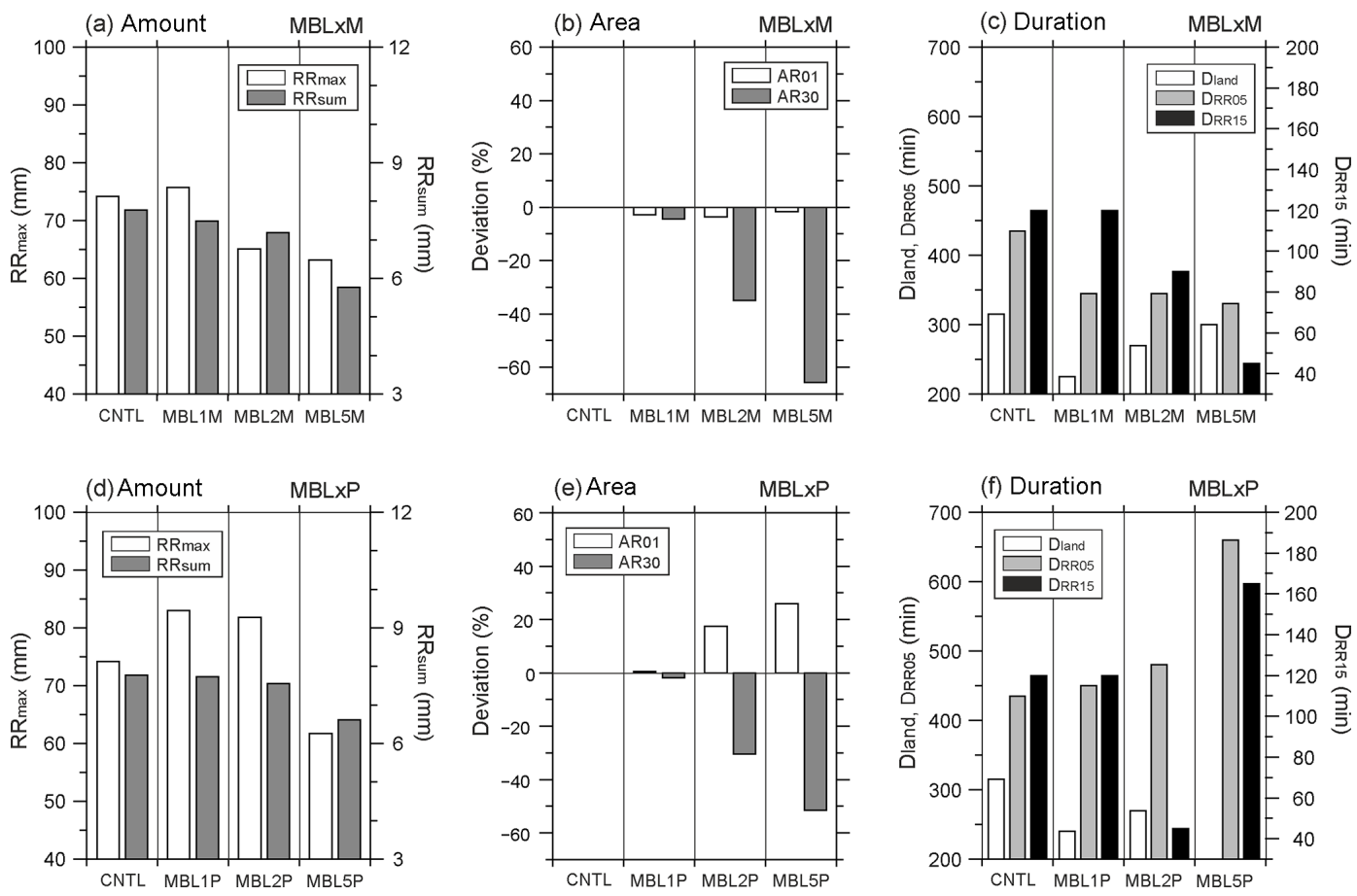

Figure 6. Results of CNTL, MBL $\times$ M (a-c) and MBL $\times \mathrm{P}(\mathbf{d}-\mathbf{f})$ experiments: panels (a) and (d) show the maximum $6 \mathrm{~h}$ accumulated precipitation amount $\left(\mathrm{RR}_{\max }\right)$ and the domain-averaged total sum of the $6 \mathrm{~h}$ accumulated precipitation amount $\left(\mathrm{RR}_{\text {sum }}, \mathrm{mm}_{)}\right.$from $12: 00 \mathrm{UTC}$ on 14 October 2012; panels (b) and (e) show the deviation of areas $\left(\mathrm{km}^{2}\right)$ of $\mathrm{RR}_{\max } \geq 1 \mathrm{~mm}(\mathrm{AR} 01)$ and $\mathrm{RR}_{\max } \geq 30 \mathrm{~mm}(\mathrm{AR} 30)$ in $\mathrm{MBL}$ to ones in CNTL; panels (c) and (f) show the duration of precipitation $(\geq 5 \mathrm{~mm})$ over the land $\left(D_{\text {land }}\right)$, duration of precipitation $\geq 5 \mathrm{~mm}$ per $15 \mathrm{~min}\left(D_{\mathrm{RR} 05}\right)$, and duration of intense precipitation $\geq 15 \mathrm{~mm}$ per $15 \mathrm{~min}\left(D_{\mathrm{RR} 15}\right)$. The $\mathrm{RR}_{\text {sum }}$ and duration of precipitation were calculated at a fixed area of latitude of $40.5-45^{\circ} \mathrm{N}$ and longitude of $3.5-9^{\circ} \mathrm{E}$, where the sensitivity bubble passed though, respectively.

tween -0.5 and $-3.4 \mathrm{~mm}$ ) is more significant than that seen over the sea $\left(\mathrm{RR}_{\text {sea }}\right.$, between -0.1 to $\left.-0.6 \mathrm{~mm}\right)$ in $\mathrm{MBL} \times \mathrm{M}$ (Table 2a). The duration of precipitation and its horizontal extent are also reduced in the MBL $\times \mathrm{M}$ experiments. The duration of intense precipitation $(\geq 15 \mathrm{~mm}$ in $15 \mathrm{~min}$, red dots in Fig. $8 \mathrm{~b}$ and c; $D_{\mathrm{RR} 15}$, black bar in Fig. 6c) are shortened by a factor of 0.75 and 0.38 in MBL2M and MBL5M, respectively, compared to CNTL (90 and $45 \mathrm{~min}$, instead of $120 \mathrm{~min}$ ). Similarly, the time for precipitation $\geq 5 \mathrm{~mm}$ $\left(D_{\mathrm{RR} 05}\right.$, grey bar in Fig. 6c) is shortened in MBL1M and MBL2M by $1.5 \mathrm{~h}$ compared to CNTL (435 min; Fig. $6 \mathrm{c}$ ).

The horizontal distribution of the $6 \mathrm{~h}$ accumulated precipitation simulated in the MBL $\times$ M experiments is displayed in Fig. $7 \mathrm{a}-\mathrm{c}$. It confirms that the precipitation accumulation is reduced, especially for the largest amounts along the eastern coastal Var region. Approximately $25 \mathrm{~mm}$ less precipitation is simulated along the eastern coast of Var in MBL1M than in CNTL (area enclosed in a solid line; Fig. 7a). In MBL2M and MBL5M, 6h accumulation precipitation along the eastern coastal region remains mainly lower than $35 \mathrm{~mm}$, whereas larger accumulations are simulated in mountainous region. Figure $6 \mathrm{~b}$ shows that the area with $\mathrm{RR}_{\max }$ in excess of $30 \mathrm{~mm}$ $\left(\mathrm{AR}_{30}\right.$, grey bars) is reduced by $4.4 \%, 35.0 \%$, and $65.7 \%$ in MBL1M, MBL2M, and MBL5M, respectively, when com- pared to CNTL, whereas the deviation of area affected by the weak precipitation, $\mathrm{RR}_{\max }$ in excess of $1 \mathrm{~mm}\left(\mathrm{AR}_{01}\right.$, white bars) is reduced only by $2.8 \%, 3.7 \%$, and $1.7 \%$ in MBL1M, MBL2M, and MBL5M, respectively.

The sensitivity bubble of MBL experiments travels northeastward over the sea as in CNTL, and it keeps its ellipse shape but with a slightly reduced horizontal size due to lateral mixing with the ambient air mass during its advection. When it arrives near the Var coast, the convection is initiated at 12:00 UTC (yellow star in Fig. 8a-c). The temporal evolution of the location and amounts of $\mathrm{RR}_{\max }$ (displayed in Fig. 8a-c) shows that, in the MBL $\times$ M experiments, precipitation $\left(\mathrm{RR}_{\max }\right.$ in excess of $\left.5 \mathrm{~mm}\right)$ starts at the same time and location as in CNTL (at 12:30 UTC) on the south-western coast of Var, about $95 \mathrm{~km}$ away from its initiation. It then shifts towards Marseille and later to the eastern coastal region of Var. In MBL2M and MBL5M (Fig. 8b-c), the largest 15 min rainfall accumulations stay longer west of $6^{\circ} \mathrm{E}$ than in CNTL (Fig. 2b). The intense precipitation ( $\geq 15 \mathrm{~mm}$ per $15 \mathrm{~min}$ ) starts $3 \mathrm{~h}$ later in MBL5M than in CNTL, MBL1M, and MBL2M. The convection at 18:00 UTC is located at the eastern coast of Var, as in CNTL (square in Fig. 2b) and $\mathrm{MBL} \times \mathrm{M}$ (square in Fig. 8a-c), and then stays $2-3 \mathrm{~h}$ additionally in this region. 

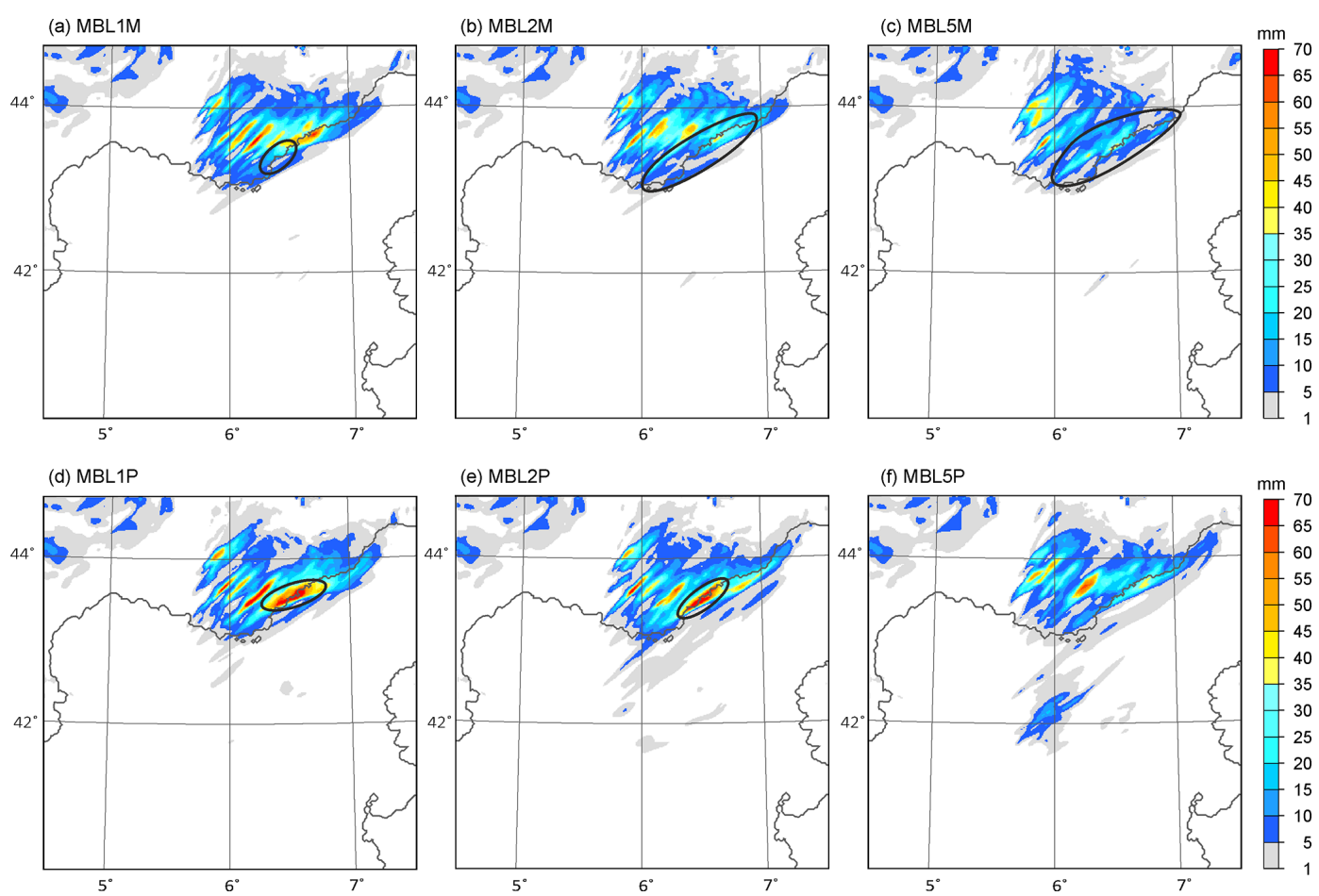

Figure 7. Distribution of the $6 \mathrm{~h}$ accumulated precipitation simulated by (a) MBL1M, (b) MBL2M, (c) MBL5M, (d) MBL1P, (e) MBL2P, and (f) MBL5P at 18:00 UTC on 14 October 2012. The black contour line shows the coast of southern France. The ellipsoid in panels (a)-(c) indicates the area with less precipitation than CNTL, while the ellipsoid in panels (d)-(e) shows the shifted precipitation area to the offshore region.

Table 2. Deviation of domain-averaged $6 \mathrm{~h}$ total accumulated precipitation amount over land $\left(\mathrm{RR}_{\text {land }}\right)$ and over sea $(\mathrm{RR}$ sea $)$ for the $\mathrm{MBL}$ and FA experiments with respect to the CNTL ( $R R_{\text {land }}$ of $14.2 \mathrm{~mm}, \mathrm{RR}_{\text {sea }}$ of $1.5 \mathrm{~mm}$ ) within the fixed area $\left(40.5-45^{\circ} \mathrm{N}, 3.5-9^{\circ} \mathrm{E}\right)$ from 12:00 UTC on 14 October 2012.

\begin{tabular}{lrrrrrr}
\hline (a) Exp. & MBL1M & MBL2M & MBL5M & MBL1P & MBL2P & MBL5P \\
\hline $\mathrm{RR}_{\text {land }}$ & -0.5 & -0.8 & -3.4 & -0.7 & -1.9 & -3.2 \\
$\mathrm{RR}_{\text {sea }}$ & -0.1 & -0.4 & -0.6 & +0.6 & +1.3 & +0.8 \\
\hline (b) Exp. & FA1M & FA2M & FA5M & FA1P & FA2P & FA5P \\
\hline RR $_{\text {land }}$ & -0.6 & -0.5 & -0.7 & -0.7 & -1.2 & -1.5 \\
$\mathrm{RR}_{\text {sea }}$ & +0.2 & +0.2 & +0.3 & +0.6 & +1.1 & +1.4 \\
\hline
\end{tabular}

To understand the reduction of the precipitation amount $\left(\mathrm{RR}_{\max }\right.$ and $\left.\mathrm{RR}_{\text {sum }}\right)$ and of the precipitating duration along the eastern Var coast, Fig. 9 shows the domain-averaged CAPE values (using a rising air parcel having its initial height at about $20 \mathrm{~m}$ ) within the sensitivity bubble upstream of the precipitation in CNTL (solid line) and MBL $\times$ M (dashed lines) from 09:30 to 14:45 UTC. At 10:00 UTC, the CAPE is reduced by about $35 \%, 67 \%$, and $95 \%$ in MBL1M, MBL2M, and MBL5M, respectively, compared to CNTL $\left(1083 \mathrm{~J} \mathrm{~kg}^{-1}\right)$. In MBL1M, MBL2M, and MBL5M, CAPE values increase gradually until 14:45 UTC but remain lower than CNTL. At 14:00 UTC, the spatial distribution of CAPE values less than $1000 \mathrm{~J} \mathrm{~kg}^{-1}$ is highlighted offshore the Var coast where the sensitivity bubble is located (i.e. $42.4-43^{\circ} \mathrm{N}$, 5.2-6 $6^{\circ}$ E, dashed ellipsoid in Fig. 10b) in MBL2M. It is worth noting that higher CAPE values $\left(>1400 \mathrm{~J} \mathrm{~kg}^{-1}\right)$ are displayed in the same region in CNTL (Fig. 10a).

Figure $11 \mathrm{a}-\mathrm{c}$ show that the warm air mass over the Mediterranean and the coastal region $\left(\theta_{\mathrm{e}}>322 \mathrm{~K}\right.$ at $\left.925 \mathrm{hPa}\right)$ is reduced in MBL $\times \mathrm{M}$ at 15:00 UTC in comparison to CNTL (Fig. 4c). The extent of cold air mass $\left(\theta_{\mathrm{v}}<291 \mathrm{~K}\right.$ at the first model level) formed along the foothill of mountain by evaporation of the intense precipitation is also reduced in MBL $\times$ M (Fig. 11a-c). Moreover, in MBL2M and MBL5M (Fig. 11b-c), the cold pool weakened further with the weakened vertical motion at the southern edge of the cold 

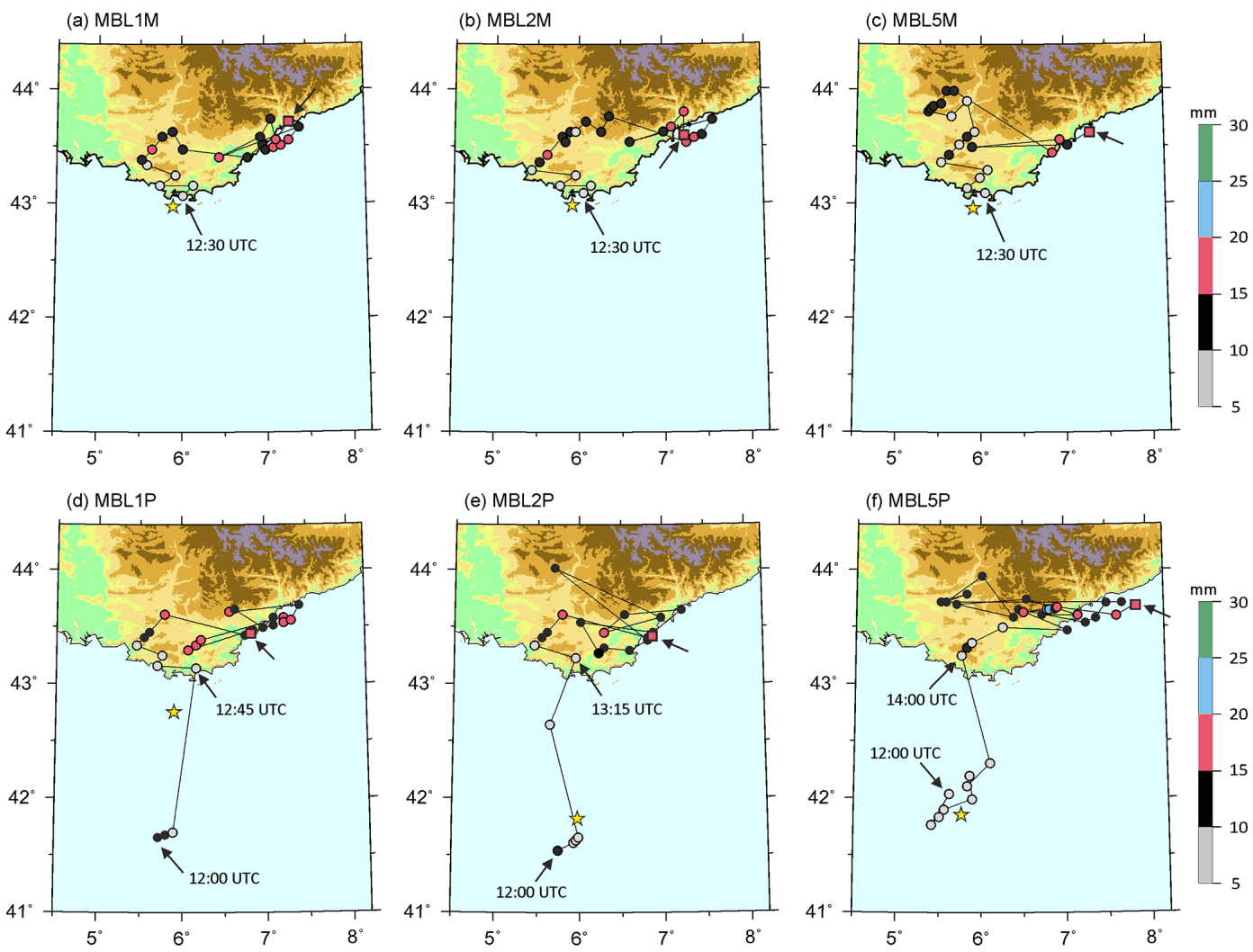

Figure 8. Evolution of the location of the maximum 15 min accumulated rainfall for $6 \mathrm{~h}$ (every 15 min from 12:00 UTC on 14 October 2012) simulated by (a) MBL1M, (b) MBL2M, (c) MBL5M, (d) MBL1P, (e) MBL2P, and (f) MBL5P. Also shown is the topography (see Fig. 1 for the scale). The location of first convection initiation is marked by a yellow star, and the last precipitating point at 18:00 UTC is marked by a square with an arrow pointing to it.

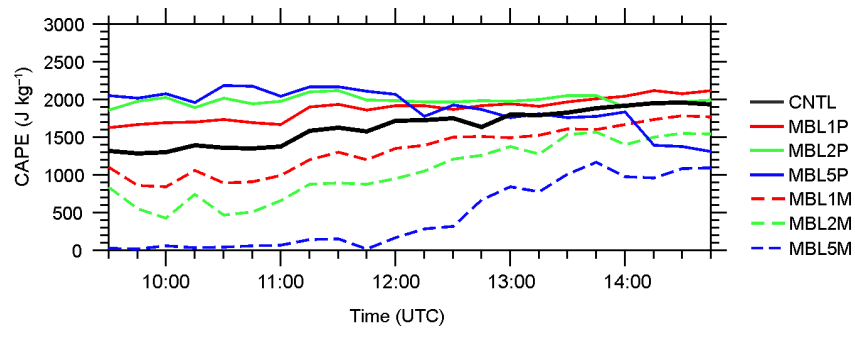

Figure 9. Temporal evolution of CAPE in the sensitivity bubble simulated in CNTL (black line), MBL $\times \mathrm{P}$ (solid lines), and MBL $\times$ M (dashed line) from 09:30 to $14: 45$ UTC on 14 October 2012 .

pool. This combination of decreased CAPE and weakened cold pool which is induced by the weakened precipitation (Fig. 7a-c) is found around the Argens valley region in particular. After 16:00 UTC, the cold air mass $\left(\theta_{\mathrm{v}}<291 \mathrm{~K}\right)$ intensifies along the eastern Var coastal region, showing the intensified vertical motion at its southern edge (not shown), and the location of $\mathrm{RR}_{\max }$ (red dots, $\geq 15 \mathrm{~mm}$ ) shifts to the north-eastern Var coast (Fig. 8a-c).
In summary, a decrease in moisture in the MABL results in a reduction of the precipitation amount intensity and in a shortening of the precipitation duration. The reduction of precipitation is highlighted both around the Argens valley region and over the eastern coast of the Var region because the lifted air is too dry to reach condensation along the coast on the mountainsides with reduced CAPE values, while larger precipitation remains in the mountainous region by the continuous supplies of low-level moist air as CNTL. 

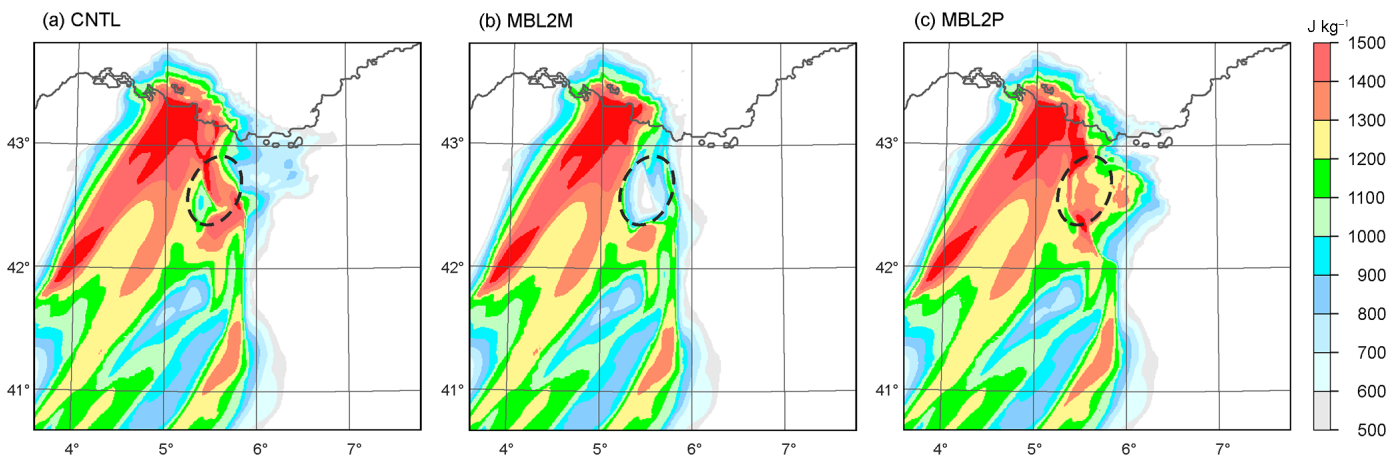

Figure 10. Distribution of CAPE simulated by (a) CNTL, (b) MBL2M, and (c) MBL2P at 14:00 UTC on 14 October 2012. The dashed ellipsoid indicates location of the sensitivity bubble. Ellipsoid indicates the area with modified CAPE in the sensitivity bubbles.
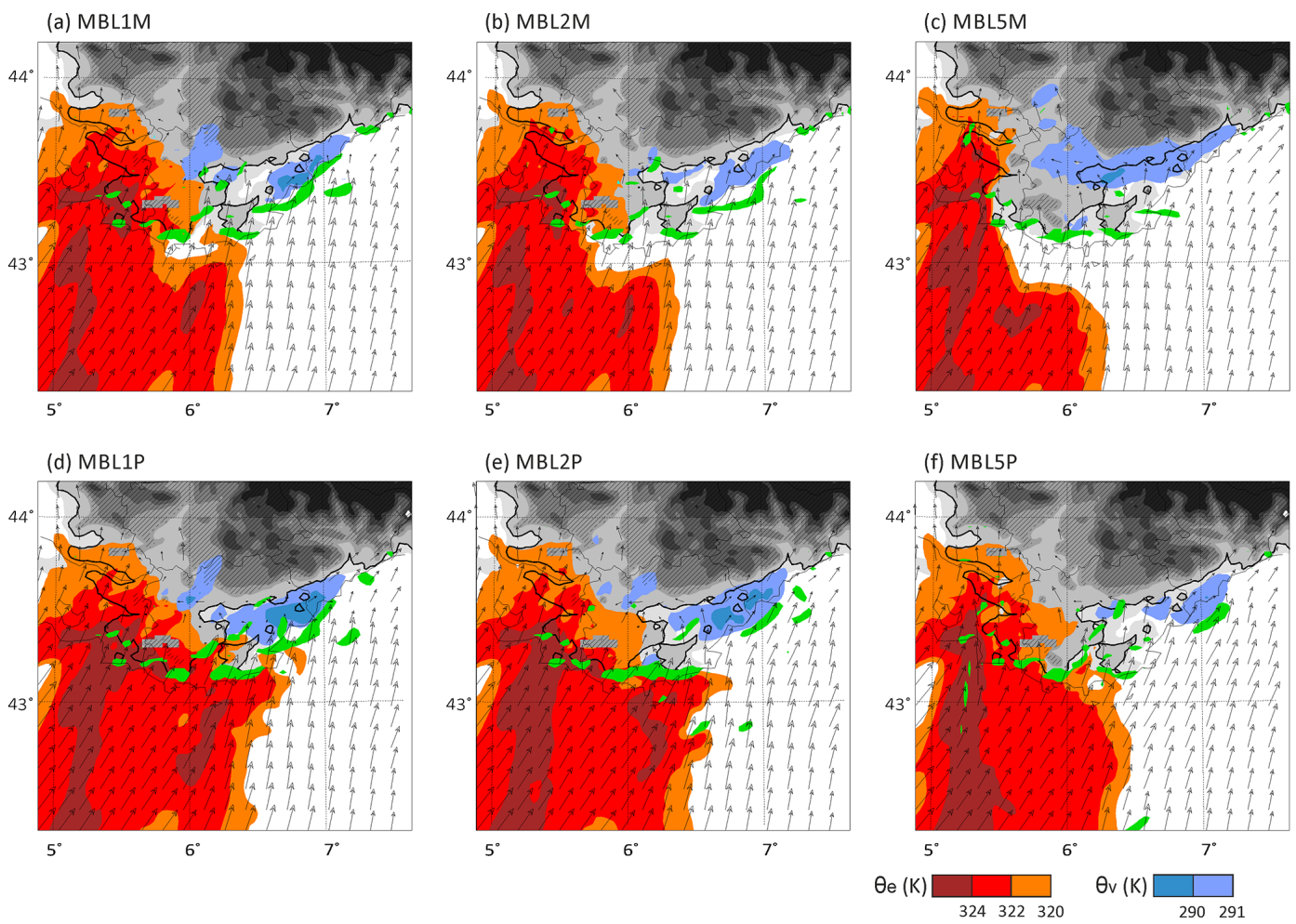

Figure 11. Equivalent potential temperature $\theta_{\mathrm{e}}$ at $925 \mathrm{hPa}\left(\mathrm{K}\right.$, red areas), virtual potential temperature $\theta_{\mathrm{v}}$ at the first model level (K, blue areas below $292 \mathrm{~K}$ ), vertical motion at $500 \mathrm{~m}$ a.s.l. (green areas above $0.5 \mathrm{~m} \mathrm{~s}^{-1}$, arrow), and horizontal wind at $925 \mathrm{hPa}$ simulated by (a) MBL1M, (b) MBL2M, (c) MBL5M, (d) MBL1P, (e) MBL2P, and (f) MBL5P at 15:00 UTC on 14 October 2012.

\subsection{Moistened marine boundary layer}

Figure 6d does not show significant differences between MBL1P and CNTL except for an increase of $\mathrm{RR}_{\max }$ (from $74.2 \mathrm{~mm}$ in CNTL to $83 \mathrm{~mm}$ in MBL1P) and a decrease of $D_{\text {land }}$ (from $315 \mathrm{~min}$ in CNTL to $240 \mathrm{~min}$ in MBL1P). In the MBL2P and MBL5P experiments, the increase of the moisture content in the MABL (0.1-1 km a.s.l.) induces more precipitation over the sea than in CNTL. For instance, excesses of $1.3 \mathrm{~mm}$ for $\mathrm{RR}_{\text {land }}$ and of $1.9 \mathrm{~mm}$ for $\mathrm{RR}_{\text {land }}$ are produced in MBL2P with respect to CNTL $\left(\mathrm{RR}_{\text {land }}\right.$ of
$14.2 \mathrm{~mm}, \mathrm{RR}_{\text {sea }}$ of $1.5 \mathrm{~mm}$ ) (Table 2a). The $D_{\mathrm{RR} 05}$ (grey bar in Fig. 6f) is increased significantly with $480 \mathrm{~min}$, and $660 \mathrm{~min}$ in MBL2P and MBL5P instead of $435 \mathrm{~min}$ in CNTL, while $D_{\text {land }}$ (white bar) is reduced in MBL2P (270 min), and MBL5P (180 min) instead of $315 \mathrm{~min}$ in CNTL. Besides, the horizontal area covered by precipitation in excess of $1 \mathrm{~mm}$ $\left(\mathrm{AR}_{01}\right.$, white bar in Fig. 6e) is enlarged by $17.4 \%$ and $26.0 \%$ in MBL2P and MBL5P, respectively, while $\mathrm{AR}_{30}$ (grey bar) is reduced by $30.5 \%$ and $51.5 \%$, respectively. This indicates more widespread but weaker precipitation in the MBL2P and MBL5P simulations. For MBL2P, $\mathrm{RR}_{\text {sum }}$ is not signif- 

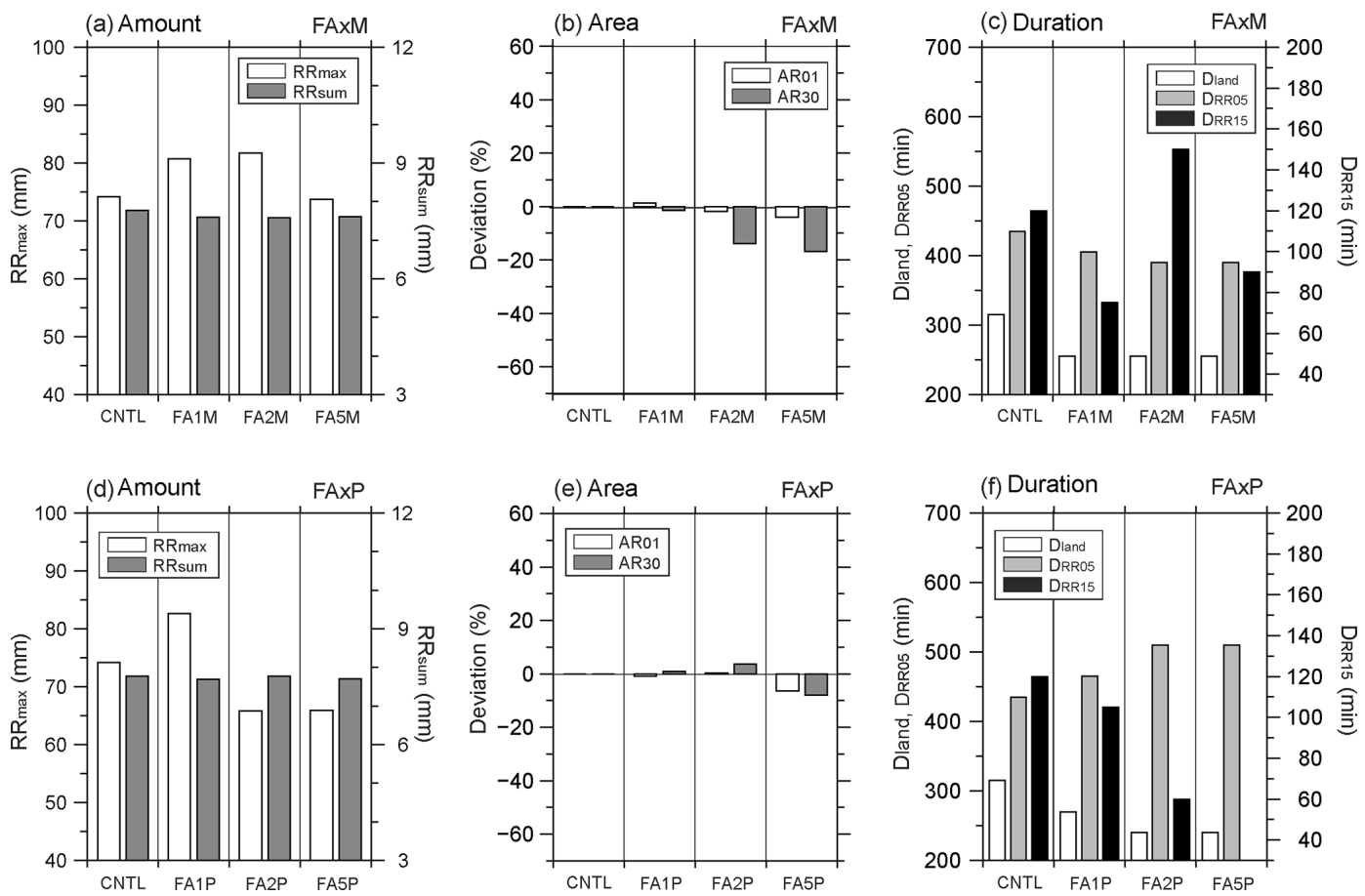

Figure 12. As Fig. 6 but for the CNTL, FA $\times M(\mathbf{a}-\mathbf{c})$, and FA $\times \mathrm{P}(\mathbf{d}-\mathbf{f})$ experiments.

icantly modified, while $\mathrm{RR}_{\max }$ increases to $81.8 \mathrm{~mm}$, more than $74.2 \mathrm{~mm}$ in CNTL, and for MBL5P, $\mathrm{RR}_{\text {sum }}$ decreases from $7.8 \mathrm{~mm}$ in CNTL to $6.6 \mathrm{~mm}$, while $\mathrm{RR}_{\max }$ decreases.

The $6 \mathrm{~h}$ accumulated precipitation in the MBL1P experiment displayed in Fig. 7d confirms that, in MBL1P, the largest accumulation on the eastern Var coast is increased (consistent with the increase of $\mathrm{RR}_{\max }$; Fig. 6d) and slightly shifted offshore (consistent with the reduced $D_{\text {land }}$; Fig. 6f) (area enclosed by solid line; Fig. 7d). This is consistently seen in the temporal evolution of the location and amounts of the maximum of $15 \mathrm{~min}$ accumulated rainfall in Fig. 8d, which shows that this accumulation is due to a stationary system blocked over the Var coast, similarly as in CNTL. The precipitating system is blocked by a cold air pool $\left(\theta_{\mathrm{v}}<291 \mathrm{~K}\right)$ over the Argens valley as shown in Fig. 11d. In the MBL $\times \mathrm{P}$ experiments (Fig. 8d-f), precipitation is initiated over the sea at 12:00 UTC, and then the bubbles travel along similar pathways over the sea as in CNTL. However, the inland precipitation starts later (e.g. 15, 45, and 90 min later in MBL1P, MBL2P, and MBL5P, respectively) than in CNTL. This late onset of inland precipitation is also consistent with more widespread precipitation over the sea in MBL2P and MBL5P (Fig. 7e, f).

For MBL2P, Fig. 7e still shows a large accumulation on the eastern Var coast due to a stationary system blocked by a cold air pool (Fig. 11e) but also an increase of weak precipitation over the sea consistent with the Fig. 6 results. The precipitation pattern in MBL5P shown in Figs. $7 \mathrm{f}$ and $8 \mathrm{f}$ is quite different from that in CNTL, with more widespread precipi- tation over the sea (around $42^{\circ} \mathrm{N}, 6^{\circ} \mathrm{E}$ ) and with much less precipitation $(64 \mathrm{~mm})$ along the eastern coast of Var (east of $\left.6^{\circ} \mathrm{E}\right)$.

The large accumulation of precipitation on the eastern Var coast and the increase of weak precipitation over the sea in MBL1P and MBL2P can be explained by the consistently high CAPE values upstream of the precipitation area from 09:30 to 14:45 UTC compared to CNTL (Fig. 9). With the high CAPE values, Fig. 8d-f also show that precipitation in the $\mathrm{MBL} \times \mathrm{P}$ simulations starts earlier over the sea than in CNTL (Fig. 2b) (consistent with the increased $D_{\mathrm{RR} 05}$ ). At 10:00 UTC, 1 and $2 \mathrm{~g} \mathrm{~kg}^{-1}$ increases in moisture in the MABL increase upstream CAPE values by $29 \%$ and $55.5 \%$ in MBL1P and MBL2P, respectively, compared to CNTL $\left(1083 \mathrm{~J} \mathrm{~kg}^{-1}\right)$. At 14:00 UTC (Fig. 10c), the high CAPE $\left(\geq 1300 \mathrm{~J} \mathrm{~kg}^{-1}\right)$ in MBL2P is seen offshore the Var coast $\left(42.5^{\circ} \mathrm{N}, 6^{\circ} \mathrm{E}\right.$, dashed ellipsoid in Fig. 10c). Figure 11d-e show that the marine air mass advected towards the coast is warmer and moister $\left(\theta_{\mathrm{e}}>324 \mathrm{~K}\right)$ in MBL1P and MBL2P than in CNTL (Fig. 4a-b). The widespread and weaker precipitation over the sea seen more particularly in MBL5P is associated with a less organized precipitating system when the moisture content in the MABL is increased. The lesser degree of organization of the convective system in MBL5P is related to the absence of a cold pool (Fig. 11f). CAPE values higher than $1500 \mathrm{~J} \mathrm{~kg}^{-1}$ lead to an increase of the degree of instability in the upstream environment (solid blue line in Fig. 9). 
In summary, increasing the WVMR in the MABL enables an earlier initiation of convection over the sea. Within the warm and moist air mass advected towards the Var region, a small increase of moisture content in the MABL favours convection triggering. Precipitation is weaker, more scattered, and widespread, especially over the sea, for a WVMR increase exceeding $2 \mathrm{~g} \mathrm{~kg}^{-1}$ in the MABL. This precipitation pattern was similarly seen in an environment of a very moist boundary layer of Bresson et al. (2012).

\section{Sensitivity to moisture between 1 and $2 \mathrm{~km}$ a.s.l. (FA experiments)}

\subsection{Dried lower troposphere between 1 and $2 \mathrm{~km}$ a.s.l.}

Decreasing moisture contents in the dry layer at $1-2 \mathrm{~km}$ a.s.l. in $\mathrm{FA} \times \mathrm{M}(\mathrm{FA} 1 \mathrm{M}, \mathrm{FA} 2 \mathrm{M}$, and $\mathrm{FA5M})$ reduces the total accumulated precipitation $\left(\mathrm{RR}_{\text {sum }}\right.$ equal to about $7.6 \mathrm{~mm}$, instead of $7.8 \mathrm{~mm}$ in CNTL; Fig. 12a). However, the total amount of precipitation simulated in the $\mathrm{FA} \times \mathrm{M}$ experiments remains larger than for $\mathrm{MBL} \times \mathrm{M}$ experiments with a drier MABL (e.g. $\mathrm{RR}_{\text {sum }}$ equal to $7.5,7.2$, and $5.8 \mathrm{~mm}$ for MBL1M, MBL2M, and MBL5M, respectively). This indicates that the precipitation amount is more sensitive to the moist air in the MABL (below $1 \mathrm{~km}$ a.s.l.) than the air just above (1-2 km a.s.l.). The duration of precipitation ( $D_{\mathrm{RR} 05}$ and $D_{\text {land }}$ ) is also reduced (Fig. 12c). Correspondingly, $\mathrm{RR}_{\text {land }}$ is reduced to between -0.5 and $-0.7 \mathrm{~mm}$ with respect to the value of $14.2 \mathrm{~mm}$ in CNTL (Table 2b). The area affected by precipitation $\left(\mathrm{AR}_{01}\right)$ is reduced as well, especially for accumulation $\geq 30 \mathrm{~mm}\left(\mathrm{AR}_{30}\right)$ and for a change of WVMR larger than $2 \mathrm{~g} \mathrm{~kg}^{-1}$ (Fig. 12b).

The horizontal distributions of the $6 \mathrm{~h}$ accumulated precipitation in the FA $\times$ M experiments are displayed in Fig. 13ac. The maximum of precipitation located along the eastern Var coast (closed circle by solid line) is about $15-20 \mathrm{~mm}$ smaller than in CNTL. The temporal evolution of the location and amounts of the maximum of $15 \mathrm{~min}$ accumulated rainfall every $15 \mathrm{~min}$ in the $\mathrm{FA} \times \mathrm{M}$ experiments is displayed in Fig. 14a-c. The sensitivity bubbles of FA experiments travel north-eastward over the sea as similar as seen in CNTL and MBL, but the horizontal extent is slightly reduced by mixing with the ambient air mass during the travel. The convection initiates about $20 \mathrm{~km}$ offshore the Var coast (yellow star; Fig. $14 \mathrm{a}-\mathrm{c}$ ). In the FA $\times$ M experiments, $\mathrm{RR}_{\max } \geq 5 \mathrm{~mm}$ starts about at the same time (or slightly later) than in CNTL. However, precipitation is initiated at a more realistic location, closer to Marseille (about $5.5^{\circ} \mathrm{E}$ ), when the bubble arrives, especially in FA2M and FA5M, instead of the southern tip of the Var region (about $6^{\circ}$ E) of CNTL (Fig. 2b).

Figure $15 \mathrm{a}-\mathrm{c}$ display the hourly evolution simulated by $\mathrm{FA} \times \mathrm{M}$ simulations of $\theta_{\mathrm{e}}$ at $925 \mathrm{hPa}$ and $\theta_{\mathrm{v}}$ at the first model level (about $10 \mathrm{~m}$ high), together with the horizontal wind and the vertical velocity at 500 m a.s.l. at 15:00 UTC.
It shows a weaker cold pool with higher $\theta_{\mathrm{v}}$ values $(\sim$ $1.5 \mathrm{~K})$ along the east coastal region of $\operatorname{Var}\left(6.2-7.2^{\circ} \mathrm{E}\right)$ in the FA $\times$ M simulations (Fig. 15a-c) compared to CNTL (Fig. 4c). The ascents (green areas) at the southern edge of the cold pool $\left(\theta_{\mathrm{v}} \leq 291 \mathrm{~K}\right)$ are consistently slightly reduced in FA $\times$ M compared to CNTL. Figure 16 shows that the rainfall intensity in the FA $\times \mathrm{M}$ simulation (dashed lines) is reduced by about $0.1-0.5 \mathrm{~mm} \mathrm{~h}^{-1}$ compared to CNTL (black line) between 12:00 and 14:30 UTC, and the rainfall intensity $\geq 0.1 \mathrm{~mm} \mathrm{~h}^{-1}$ starts about $45 \mathrm{~min}$ later (13:00 UTC, dashed line) than in CNTL (12:15 UTC, black line). Under the weakened precipitation, evaporation rate is reduced. The corresponding values of $\theta_{\mathrm{v}}$ in the $\mathrm{FA} \times \mathrm{M}$ simulations are increased by about $0.2-0.5 \mathrm{~K}$ with respect to CNTL (dashed line; Fig. 16b). Considering the region immediately upstream of convective ascents, the total moisture below $2 \mathrm{~km}$ in the $\mathrm{FA} \times \mathrm{M}$ simulations is lower than in CNTL due to the advection of the sensitivity bubble containing dry air at heights between 1 and $2 \mathrm{~km}$. With the reduced moisture in the lower troposphere, the triggered convection near the Var coast produces less intensive rainfall and the weakened cold pool. This is consistent with the reduction of the rainfall accumulation over the Var coast in the FA $\times$ M simulations. Modifying the moisture content in the dry layer at $1-2 \mathrm{~km}$ a.s.l. does not change much the CAPE values upstream of the precipitation (not shown). The CAPE values in both CNTL and FA $\times$ M slightly increased over time from 1083 to $1650 \mathrm{~J} \mathrm{~kg}^{-1}$ in the location of the sensitivity bubble as it mixed with the adjacent moister air (not shown).

In summary, decreasing the moisture content in the dry layer between 1 and $2 \mathrm{~km}$ a.s.l. reduces the total amount of precipitation as well as the area affected by the precipitation and the duration of the precipitating episode. As the MABL is nearly saturated, the convection triggers easily along the coast but develops less intensively. The maximum of precipitation located along the eastern Var coast is reduced, corresponding to a weakened cold pool and weakened ascents at its southern boundary. This shows that, around the coast, the dryness in the 1-2 km a.s.l. layer is not a major ingredient for the convection development and the cold pool generation when the lowermost layer is nearly saturated.

\subsection{Moistened lower troposphere between 1 and 2 km a.s.l.}

The FA $\times \mathrm{P}(\mathrm{FA} 1 \mathrm{P}, \mathrm{FA} 2 \mathrm{P}$, and FA5P) experiments with increased moisture content in the free troposphere between 1 and $2 \mathrm{~km}$ a.s.l. produced a similar total precipitation accumulation ( $\mathrm{RR}_{\text {sum }}$ about $7.7 \mathrm{~mm}$ in Fig. 12d) to CNTL (7.8 mm). The duration of precipitation $\left(D_{\mathrm{RR} 05}\right)$ is prolonged from $435 \mathrm{~min}$ in CNTL to 465,510 , and $510 \mathrm{~min}$, in FA1P, FA2P, and FA5P, respectively (Fig. 12f). However, the duration of precipitation over land ( $\left.D_{\text {land }}\right)$ and the duration of more intense precipitation $\left(D_{\mathrm{RR} 15}, \geq 15 \mathrm{~mm}\right.$ in $\left.15 \mathrm{~min}\right)$ are shorter in the FA $\times \mathrm{P}$ experiments than in CNTL. Table $2 \mathrm{~b}$ shows 

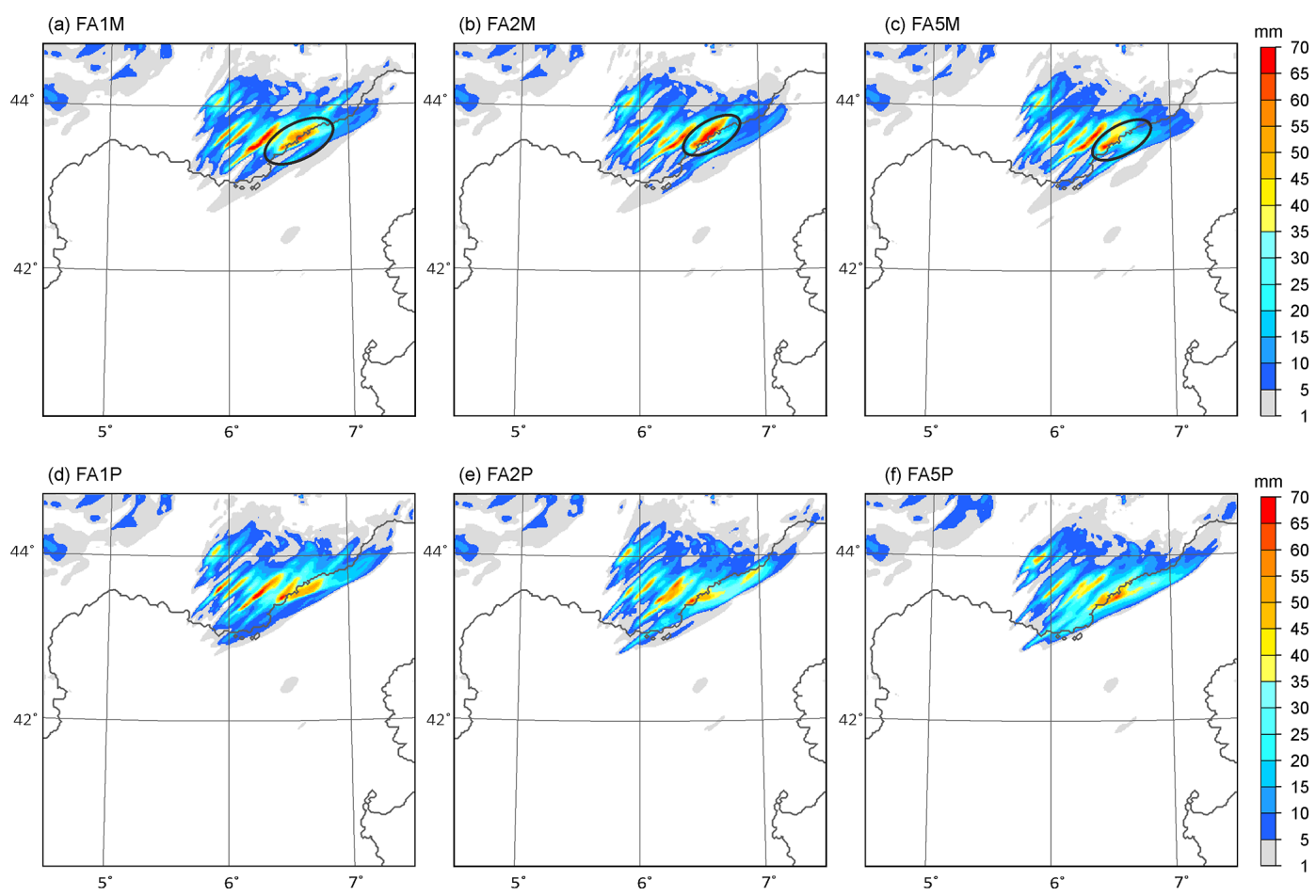

Figure 13. Same as Fig. 7 for (a) FA1M, (b) FA2M, (c) FA5M, (d) FA1P, (e) FA2P, and (f) FA5P. In panels (a)-(c), the reduced precipitation around the coast is indicated by a closed ellipsoid with a solid line.

(a) FA1M

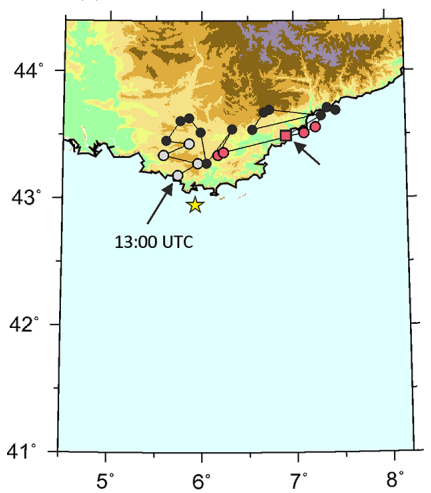

(d) FA1P

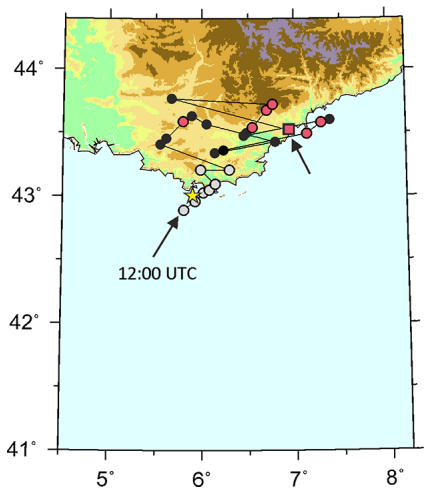

(b) FA2M

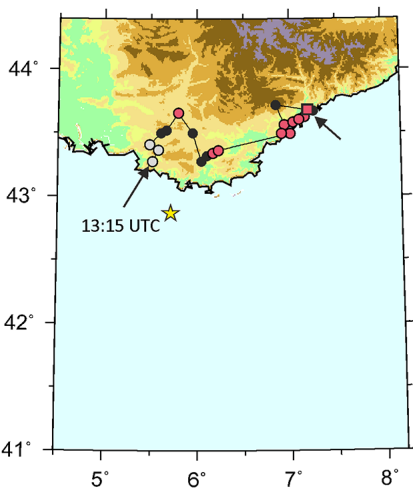

(e) FA2P

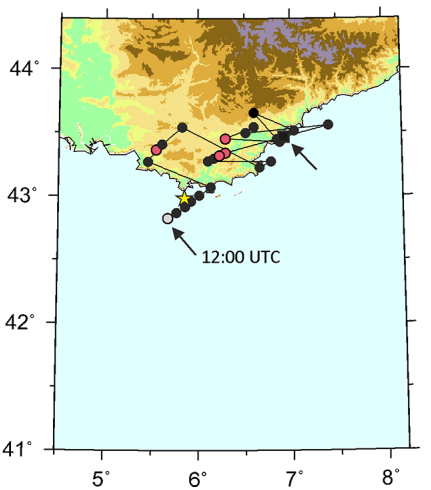

(c) FA5M

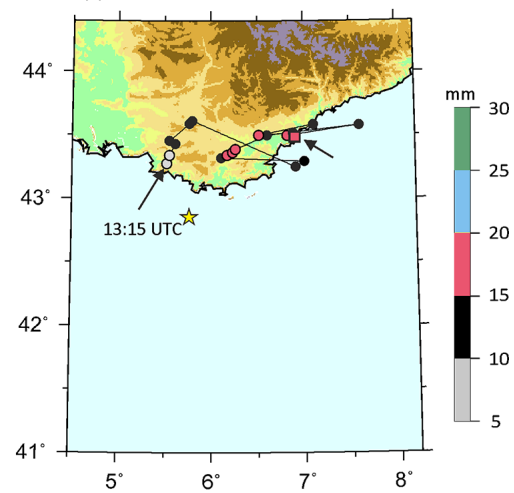

(f) FA5P

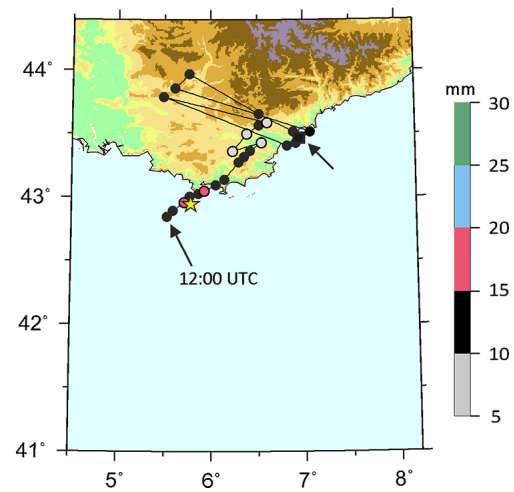

Figure 14. Same as Fig. 8 for (a) FA1M, (b) FA2M, (c) FA5M, (d) FA1P, (e) FA2P, and (f) FA5P. 
(a) FA1M

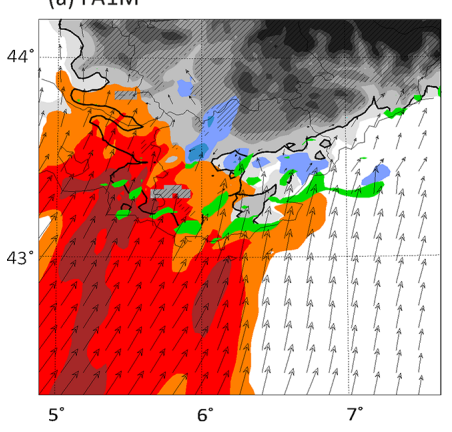

(d) FA1P

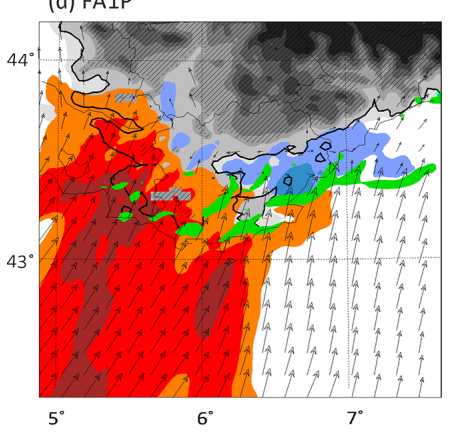

(b) FA2M

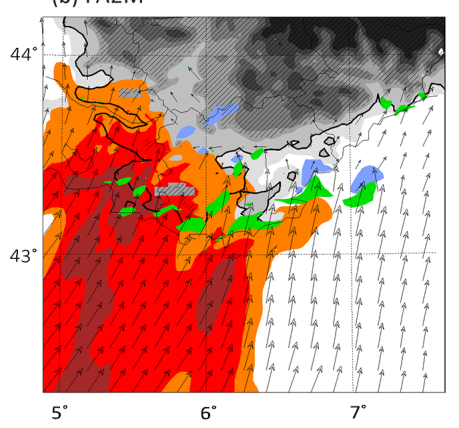

(e) FA2P

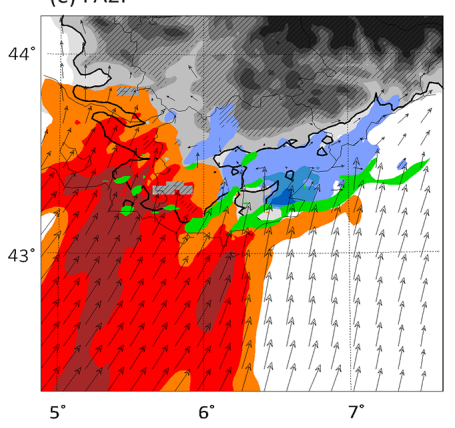

(c) FA5M

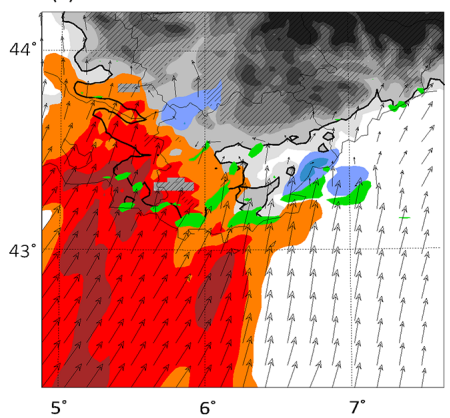

(f) FA5P

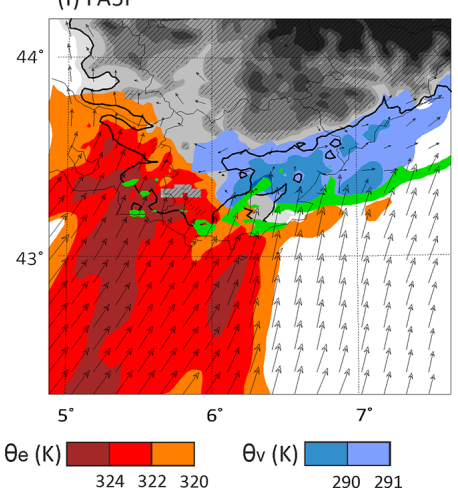

Figure 15. Same as Fig. 11 for (a) FA1M, (b) FA2M, (c) FA5M, (d) FA1P, (e) FA2P, and (f) FA5P at 15:00 UTC on 14 October 2012.

(a)
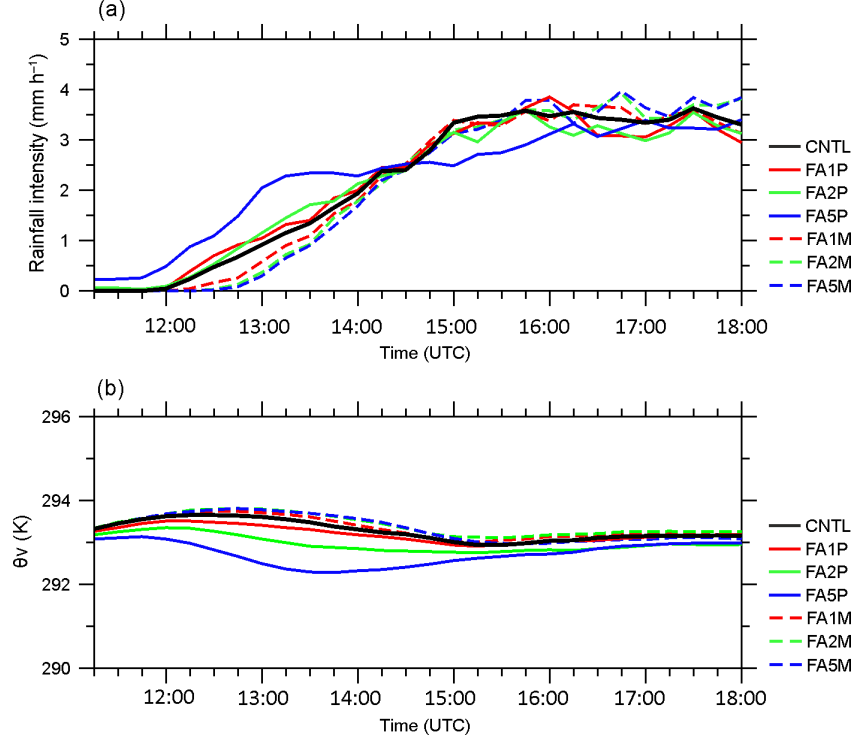

Figure 16. Temporal evolution of domain-averaged rainfall intensity $\left(\mathrm{mm} \mathrm{h}^{-1}\right)$ and virtual potential temperature $\left(\theta_{\mathrm{V}}\right)$ at the first model level in a fixed domain of $43-44.5^{\circ} \mathrm{N}, 5.5-7.5^{\circ} \mathrm{E}$, where most of the precipitation is produced by CNTL (black line), FA $\times \mathrm{P}$ (solid lines), and FA $\times$ M (dashed lines) from 11:15 to 18:00 UTC on 14 October 2012.

the reduced $R_{\text {land }}$ values between -0.7 and $-1.5 \mathrm{~mm}$ in
FA $\times$ P, with respect to CNTL $(1.5 \mathrm{~mm})$, as well as the increased $R_{\text {sea }}$ values between +0.6 and $+1.4 \mathrm{~mm}$. The areas of precipitation $\left(\mathrm{AR}_{01}\right.$ and $\left.\mathrm{AR}_{30}\right)$ are not modified much in the FA1P and FA2P simulations and both are slightly reduced in FA5P (Fig. 12e).

The horizontal distribution of the $6 \mathrm{~h}$ accumulated precipitation in the FA $\times \mathrm{P}$ experiments is displayed in Fig. $13 \mathrm{~d}-$ $\mathrm{f}$. The precipitation pattern is not modified much, but the maximum precipitation amount over the eastern coastal region of Var is slightly shifted offshore and reduced mainly in FA2P and FA5P (with 65.8 and $65.9 \mathrm{~mm}$ instead of $74.2 \mathrm{~mm}$ in CNTL, east of $6^{\circ} \mathrm{E}$; Fig. 13e and f).

The temporal evolution of the location and amount of the maximum of $15 \mathrm{~min}$ accumulated rainfall every $15 \mathrm{~min}$ in the FA $\times$ P experiments (Fig. 14d-f) shows that increasing the moisture contents in the dry layer between 1 and $2 \mathrm{~km}$ a.s.l. induces an initiation of the precipitation about $1 \mathrm{~h}$ earlier than in CNTL (consistent with the increase of $D_{\mathrm{RR} 05}$ ). The convection initiates near the Var coast, as in CNTL; however, the horizontal extent of the convective region (reflectivity $\geq 45 \mathrm{dBZ}$ ) is relatively large compared to CNTL. The precipitation starts at 12:00 UTC about $50 \mathrm{~km}$ offshore the southern Var coast, when the bubble reaches this region $\sim 140 \mathrm{~km}$ distant from the location of initiation, with larger 15 min accumulation values (10-20 mm, black and red dots in Fig. 14e-f, compared to grey dots $<10 \mathrm{~mm}$ in CNTL in Fig. 2b). 
(a) Moistened MBL

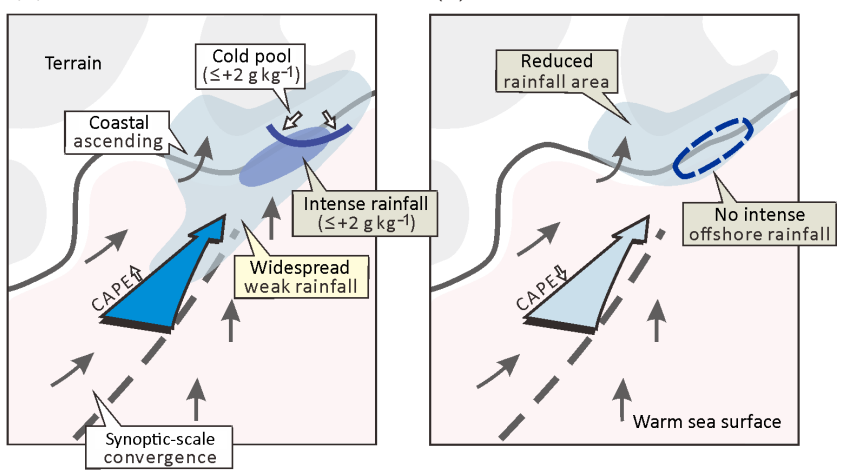

(c) Moistened FA (1-2 km a.s.I.)

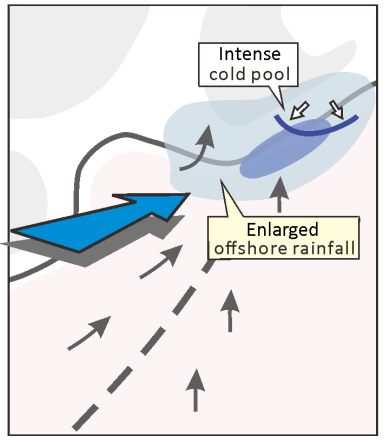

(d) Dried FA (1-2 km a.s.I.)

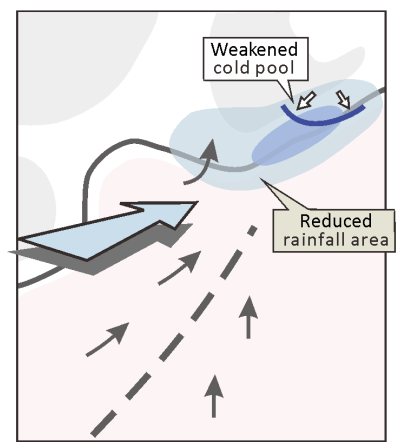

Figure 17. Schematics summarizing the main features of the impact of upstream moisture in MBL in panels (a) and (b), and in the free atmosphere (FA) layer between 1 and $2 \mathrm{~km}$ a.s.l. in panels (c) and (d) on back-building heavy precipitation in south-eastern France during HyMeX IOP13. Dark blue arrows in panels (a) and (c) and light blue arrows in panels (b) and (d) indicate the moistened and dried upstream air masses, respectively. In panels (a)-(d), black arrows and a broken line indicate the low-level wind and the synoptic-scale wind convergence line, respectively. The light blue region depicts the weak precipitation area, while the dark blue region shows the intense precipitation area. The blue solid line illustrates the southern edge of cold pool, while the closed area with blue dashed line in panels (b) and (d) indicates the absence of intense offshore rainfall.

Regarding the large precipitation around the southern Var coast and its enlarged horizontal extent of the convective region in FA2P and FA5P, Fig. 15e-f show the large affected area by the cold pool $\left(\theta_{\mathrm{v}}<291 \mathrm{~K}\right)$ compared to CNTL (Fig. 4a) at 15:00 UTC. Figure 16a shows the enhanced rainfall intensities (about $0.2-2.5 \mathrm{~mm} \mathrm{~h}^{-1}$ ) in the FA $\times \mathrm{P}$ simulations (coloured solid lines) compared to CNTL (black line) between 12:00 and 14:30 UTC; especially FA5P produces the precipitation about 45 min earlier in time. Under the intensifying precipitation, the values of $\theta_{\mathrm{v}}$ in the FA $\times \mathrm{P}$ simulations are about $0.2-1.7 \mathrm{~K}$ reduced, indicating the intensified cold pool formed by evaporative cooling compared to CNTL (Fig. 16b). As the moistened air mass in the $1-2 \mathrm{~km}$ layer mixed with the moist air below during its advection towards the region of upstream convection, the total moisture below
$2 \mathrm{~km}$ a.s.l. increased. Thanks to the moistened lower troposphere, the convection triggered near the Var coast produces more intensive rainfall and correspondingly a more intense cold pool. Also, the moistened air masses in the lower troposphere initiate precipitation earlier while the precipitating area, particularly over the sea, is enlarged. In FA $\times$ P, the duration of the entire episode is increased, but the intensity of the precipitation is reduced (red dots in Fig. $14 \mathrm{~d}-\mathrm{f}$; $D_{\mathrm{RR} 15}$ decreases in Fig. 12f). It also appears that the precipitation is less stationary.

In summary, increasing the moisture content in the dry lower troposphere between 1 and $2 \mathrm{~km}$ a.s.l. enlarges the precipitating area, particularly over the sea. With the moistened air mass in the 1-2 km a.s.l. layer, similar CAPE values $\left(\geq 1050 \mathrm{~J} \mathrm{~kg}^{-1}\right)$ were calculated offshore the Var coast in the FA $\times \mathrm{P}$ experiments and in CNTL. In the environment with similar instability but with further moistened conditions in the lower troposphere, the triggered convection further intensifies with the enlarged horizontal extent of cold pool and strengthened ascents at its southern boundary.

\section{Summary}

The present study examines the impact of the environmental moisture structure of the lower troposphere (below $2 \mathrm{~km}$ a.s.l.) on the precipitation development and organization, observed in southern France during IOP13 of the HyMeX SOP-1, through a series of sensitivity experiments using the non-hydrostatic numerical model Meso$\mathrm{NH}$. The moisture structure upstream of the IOP13 HPE is characterized by a moist conditionally unstable MABL (below $1 \mathrm{~km}$ a.s.1.) topped by a dry air mass just above (1$2 \mathrm{~km}$ a.s.l.). A CNTL simulation shows that the moisture supply to the precipitating system is provided by the moist air mass of the MABL, while the dry air mass between 1 and $2 \mathrm{~km}$ a.s.l. is involved in the formation of a cold pool. Focusing on these two layers, namely (1) a moist layer from 0.1 to $1 \mathrm{~km}$ a.s.l., and (2) a dry layer from 1 to $2 \mathrm{~km}$ a.s.l., $12 \mathrm{sen}$ sitivity experiments were carried out to study the influence of upstream moisture structure in the lower troposphere on convection development that occurred in southern France.

The CNTL simulation, as well as all the other sensitivity experiments examined in this study, succeeds in reproducing heavy precipitation in the coastal mountainous region of Var in south-eastern France. Through comparisons between CNTL and the 12 sensitivity experiments, we show how the life cycle of precipitation is modified even for moisture content changes as small as $1 \mathrm{~g} \mathrm{~kg}^{-1}$ below $2 \mathrm{~km}$ a.s.l. The results are summarized schematically in Fig. 17. Increasing the moisture content by 1,2 , or $5 \mathrm{~g} \mathrm{~kg}^{-1}$ in the MABL (0.1$1 \mathrm{~km}$ a.s.1.) (see Fig. 17a) induces an earlier initiation of precipitation offshore the Var region (light blue area) with an increase of CAPE values, as well as longer-lasting precipitation. A small increase of moisture content in the warm 
and moist MABL increases the degree of instability. In the environment with an increase of the MABL moisture content lower than $2 \mathrm{~g} \mathrm{~kg}^{-1}$, precipitation developing offshore arrives at the coastal region of Var with the low-level southwesterlies warm and moist air and anchors over the coasts as it is blocked by a cold pool (blue line). For an increase of the moisture content exceeding $2 \mathrm{~g} \mathrm{~kg}^{-1}$, the area of intense precipitation around the coastal region is reduced and the precipitating system is less stationary because of a weakened cold pool.

Similarly, moistening the layer at 1-2 kma.s.l. (see Fig. 17c), just above the MABL, increases the humidity in the lowermost $2 \mathrm{~km}$ a.s.l. by mixing in the environment with a similar instability as in CNTL. With more moisture in lower troposphere, the triggered convection further intensifies, which produces an enlargement of the horizontal extent of cold pools (dark blue area). Also, it produces precipitation earlier offshore (light blue area) but does not increase the total amount of precipitation much. Precipitation lasts longer and affects a larger area, particularly over the sea.

A drier MABL (Fig. 17b) shortens the lifetime of precipitation and reduces the total precipitation amount. For instance, a $2 \mathrm{~g} \mathrm{~kg}^{-1}$ decreased moisture content in the MABL results in a reduction of about $10 \%$ in terms of total precipitation in the coastal regions of Var (closed area with blue broken line) and in a reduction of about $67 \%$ in terms of CAPE. A drier lower troposphere in the 1-2 km a.s.l. layer (see Fig. 17d) also contributes to reducing the precipitating area (light blue area) with rainfall accumulation located more inland rather than over the coastal region because of a weakened cold pool. Also, it is true that dried air mass in the region of 1-2 km a.s.l. initiates precipitation at a more accurate location, about $25 \mathrm{~km}$ closer to Marseille. Decreasing the moisture content in the MABL has a stronger impact on precipitation both in terms of amount and intensity than decreasing the moisture content in the layer just above (1-2 km a.s.l.). The dryness in the $1-2 \mathrm{~km}$ a.s.l. layer is not a major ingredient for the convection development and the cold pool generation when the lowermost layer is nearly saturated.

Despite a simplified moisture-profile modification approach, this study suggests that moisture structure in the lower troposphere (below $2 \mathrm{~km}$ a.s.l.) is key for an accurate prediction of the timing and location of precipitation in the coastal mountainous region (e.g. the Var region) in southern France. At the same time, this study shows the importance of accurate moisture content (amount and profile) in the initial field to reproduce realistic convective systems, emphasizing the importance of high-resolution and threedimensional moisture observation upstream of the HPE, especially over the sea. This study focused on the impact of moisture contents on precipitation development in southern France, and the HPE which occurred during IOP13 of the HyMeX SOP-1. It would be interesting to consider other regions in the Mediterranean basin by analysing additional HPE cases of SOP-1 when interesting moisture structure, in- cluding the presence of dry air masses above $2 \mathrm{~km}$ a.s.l. upstream of the HPE, was identified, e.g. IOP13 in south Italy (Lee et al., 2016) and IOP8 in the north-east of the Iberian Peninsula (Bouin et al., 2017). By accumulating the eventscale analysis in other regions of the Mediterranean basin, we can expand our knowledge of what is the general impact of upstream water vapour on precipitation (e.g. categories of synoptic conditions). Another approach is to use stable water isotopologue data to disentangle the various moisture sources, i.e. evaporation over the sea, advected moisture upstream of the HPEs in the Mediterranean (Sodemann et al., 2017).

Data availability. Meso-NH output data are available from the authors upon request (keun-ok.lee@aero.obs-mip.fr).

Author contributions. KOL, CF, FD, and VD planned the manuscript and analyses. KOL and FD designed the numerical simulation and KOL performed it. All co-authors contributed to discussion. KOL prepared the manuscript with contributions from all co-authors.

Competing interests. The authors declare that they have no conflict of interest.

Special issue statement. This article is part of the special issue "Hydrological cycle in the Mediterranean (ACP/AMT/GMD/HESS/NHESS/OS inter-journal SI)". It is not associated with a conference.

Acknowledgements. This work was supported by the French Agence Nationale de la Recherche (ANR) via the IODA-MED grant ANR-11-BS56-0005, the MUSIC grant ANR-14-CE01-014, and the MISTRALS/HyMeX programme. This work was partly supported by DRIHM.

Edited by: Heini Wernli

Reviewed by: three anonymous referees

\section{References}

Argence, S., Lambert, D., Richard, E., Chaboureau, J. P., and Söhne, N.: Impact of initial condition uncertainties on the predictability of heavy rainfall in the Mediterranean: a case study, Q. J. Roy. Meteor. Soc., 134, 1775-1788, https://doi.org/10.1002/qj.314, 2008.

Barthlott, C. and Davolio, S.: Mechanisms initiating heavy precipitation over Italy during the HyMeX Special Observation Period 1: A numerical case study using two mesoscale models, Q. J. Roy. Meteor. Soc., 142, 238-258, https://doi.org/10.1002/qj.2630, 2015. 
Bielli, S., Grzeschik, M., Richard, E., Flamant, C., Champollion, C., Kiemle, C., Dorninger, M., and Brousseau, P.: Assimilation of water-vapour airborne lidar observations: impact study on the COPS precipitation forecasts, Q. J. Roy. Meteor. Soc., 138, 1652-1667, 2012.

Bougeault, P. and Lacarrère, P.: Parameterization of orographyinduced turbulence in a meso-beta-scale model, Mon. Weather Rev., 117, 1872-1890, 1989.

Bouin, M. N., Redelsperger, J. L., and Leveaupin, B. C.: Processes leading to deep convection and sensitivity to sea-state representation during HyMeX IOP8 heavy precipitation event, Q. J. Roy. Meteor. Soc., 143, 2600-2615, https://doi.org/10.1002/qj.3111, 2017.

Bresson, E., Ducrocq, V., Nuissier, O., Ricard, D., and de Saint-Aubin C.: Idealized numerical simulations of quasistationary convective systems over the Northwestern Mediterranean complex terrain, Q. J. Roy. Meteor. Soc., 138, 1751-1763, https://doi.org/10.1002/qj.1911, 2012.

Buzzi, A., Tartaglione, N., and Malguzzi, P.: Numerical simulations of the 1994 Piemont flood: Role of the orography and moist processes, Mon. Weather Rev., 126, 2369-2383, 1998.

Caniaux, G., Redelsperger, J. L., and Lafore, J. P.: A numerical study of the stratiform region of a fast-moving squall line, J. Atmos. Sci., 51, 2046-2074, 1994.

Carpenter, K.: Note on the paper: Radiational condition for the lateral boundaries of limited-area numerical models by MJ Miller and AJ Thorpe, Q. J. Roy. Meteor. Soc., 108, 717-719, 1982.

Chazette, P., Flamant, C., Raut, J. C., Totems, J., and Shang, X.: Tropical moisture enriched storm tracks over the Mediterranean and their link with intense rainfall in the Cevennes-Vivarais area during HyMeX, Q. J. Roy. Meteor. Soc., 142, 320-334, https://doi.org/10.1002/qj.2674, 2016.

Clark, H. and Chaboureau, J. P.: Uncertainties in short-term forecasts of Mediterranean heavy precipitation event: Assessment with satellite observations, J. Geophys. Res., 115, D22213, https://doi.org/10.1029/2010JD014388, 2010.

Colella, P. and Woodward, P. R.: The piecewise parabolic method (PPM) for gas dynamical simulations, J. Comput. Phys., 54, 174201, https://doi.org/10.1016/0021-9991(84)90143-8, 1984.

Crook, N. A.: Sensitivity of moist convection forced by boundary layer processes to low-level thermodynamic fields, Mon. Weather Rev., 124, 1767-1785, 1996.

Cuxart, J., Bougeault, P., and Redelsperger, J. L.: A turbulence scheme allowing for mesoscale and largeeddy simulations, Q. J. Roy. Meteor. Soc., 126, 1-30, https://doi.org/10.1002/qj.49712656202, 2000.

Davies, H.: A lateral boundary formulation for multi-level prediction models, Q. J. Roy. Meteor. Soc., 102, 405-418, 1976.

Ducrocq, V., Ricard, D., Lafore, J. P., and Orain, F.: Storm-scale numerical rainfall prediction for five precipitating events over France: On the importance of the initial humidity field, Weather and Forecast., 17, 1236-1256, 2002.

Ducrocq, V., Nuissier, O., Ricard, D., Lebeaupin, C., and Thouvenin, R.: A numerical study of three catastrophic precipitating events over southern France, Mesoscale triggering and stationarity factors, Q. J. Roy. Meteor. Soc., 134, 131-145, 2008.

Ducrocq, V., Braud, I., Davolio, S., Ferretti, R., Flamant, C., Jansa, A., Kalthoff, N., Richard, E., Taupier-Letage, I., Ayral, P.A., Belamari, S., Berne, A., Borga, M., Boudevillain, B., Bock, O.,
Boichard, J. L., Bouin, M. N., Bousquet, O., Bouvier, C., Chiggiato, J., Ciimini, D., Corsmeier, U., Coppola, L., Cocquerez, P., Defer, E., Delanoë, J., Di Girolamo, P., Doerenbecher, A., Drobinski, P., Dufournet, Y., Fourrié, N., Gourley, J.J., Labatut, L., Lambert, D., Le Coz, J., Marzano, F.S., Molinié, G., Montani, A., Nord, G., Nuret, M., Ramage, K., Rison, W., Roussot, O., Said, F., Schwarzenboeck, A., Testor, P., Van Baelen, J., Vincendon, B., Aran, M., and Tamayo, J.: HyMeX-SOP1: The Field Campaign Dedicated to Heavy Precipitation and Flash Flooding in the Northwestern Mediterranean, Bull. Am. Meteorol. Soc., 95, 1083-1100, https://doi.org/10.1175/BAMS-D-1200244.1, 2014.

Ducrocq, V., Davolio, S., Ferretti, R., Flamant, C., Santaner, V. H., Kalthoff, N., Richard, E., and Wernli, H.: Introduction to the HyMeX Special Issue on "Advances in understanding and forecasting of heavy precipitation in the Mediterranean through the HyMeX SOP1 field campaign”, Q. J. Roy. Meteor. Soc., 142, 16, 2016

Duffourg, F. and Ducrocq, V.: Origin of the moisture feeding the Heavy Precipitating Systems over Southeastern France, Nat. Hazards Earth Syst. Sci., 11, 1163-1178, https://doi.org/10.5194/nhess-11-1163-2011, 2011.

Duffourg, F., Nuissier, O., Ducrocq, V., Flamant, C., Chazette, P., Delanoë, J., Doerenbecher, A., Fourrié, N., Di Girolamo, P., Lac, C., Legain, D., Martinet, M., Saïd, F., and Bock, O.: Offshore deep convection initiation and maintenance during the HyMeX IOP 16a Heavy Precipitation Event, Q. J. Roy. Meteor. Soc., 142, 259-274, https://doi.org/10.1002/qj.2725, 2016.

Duffourg, F., Lee, K. O., Ducrocq, V., Flamant, C., Chazette, P., and Di Girolamo, P.: Role of moisture patterns in the backbuilding formation of HyMeX IOP13 Heavy Precipitating Systems, Q. J. Roy. Meteor. Soc., 144, 291-303, https://doi.org/10.1002/qj.3201, 2018.

Fourrié, N., Bresson, É., Nuret, M., Jany, C., Brousseau, P., Doerenbecher, A., Kreitz, M., Nuissier, O., Sevault, E., Bénichou, H., Amodei, M., and Pouponneau, F.: AROME-WMED, a real-time mesoscale model designed for the HyMeX special observation periods, Geosci. Model Dev., 8, 1919-1941, https://doi.org/10.5194/gmd-8-1919-2015, 2015.

Gal-Chen, T. and Somerville, R. C. J.: On the use of a coordinate transformation for the solution of the Navier-Stokes equations, J. Comput. Phys., 17, 209-228, https://doi.org/10.1016/00219991(75)90037-6, 1975.

Houze, R. J.: Cloud Dynamics, International Geophysics Vol. 53, Academic Press: New York, NY, 1993.

Jansa, A., Genoves, A., Picornell, M. A., Campins, J., Riosalido, R., and Carretero, O.: Western Mediterranean cyclones and heavy rain. Part 2: Statistical approach, Meteorol. Appl., 8, 43-56, https://doi.org/10.1017/S1350482701001049, 2001.

Lac, C., Chaboureau, J. P., Masson, V., Pinty, J. P., Tulet, P., Escobar, J., Leriche, M., Barthe, C., Aouizerats, B., Augros, C., Aumond, P., Auguste, F., Bechtold, P., Berthet, S., Bielli, S., Bosseur, F., Caumont, O., Cohard, J. M., Colin, J., Couvreux, F., Cuxart, J., Delautier, G., Dauhut, T., Ducrocq, V., Filippi, J. B., Gazen, D., Geoffroy, O., Gheusi, F., Honnert, R., Lafore, J. P., Lebeaupin, Brossier C., Libois, Q., Lunet, T., Mari, C., Maric, T., Mascart, P., Mogé, M., Molinié, G., Nuissier, O., Pantillon, F., Peyrillé, P., Pergaud, J., Perraud, E., Pianezze, J., Redelsperger, J. L., Ricard, D., Richard, E., Riette, S., Rodier, Q. 
Schoetter, R., Seyfried, L., Stein, J., Suhre, K., Taufour, M., Thouron, O., Turner, S., Verrelle, A., Vié, B., Visentin, F., Vionnet, V., and Wautelet, P.: Overview of the Meso-NH model version 5.4 and its applications, Geosci. Model Dev., 11, 19291969, https://doi.org/10.5194/gmd-11-1929-2018, 2018.

Lee, K. O., Uyeda, H., Shimizu, S., and Lee, D. I.: Dual-Doppler radar analysis of the enhancement of a precipitation system on the northern side of Mt. Halla, Jeju Island, Korea on 6 July 2007, Atmos. Res., 118, 133-152, 2012.

Lee, K. O., Flamant, C., Ducrocq, V., Duffourg, F., Fourrié, N., and Davolio, S.: Convective initiation and maintenance processes of two back-building mesoscale convective systems leading to heavy precipitation events in Southern Italy during HyMeX IOP 13, Q. J. Roy. Meteor. Soc., 142, 2623-2635, https://doi.org/10.1002/qj.2978, 2016.

Lee, K. O., Flamant, C., Ducrocq, V., Duffourg, F., Fourrié, N., Delanoë, J., and Bech, J.: Initiation and development of a mesoscale convective system in the Ebro River Valley and related heavy precipitation over northeastern Spain during HyMeX IOP15a, Q. J. Roy. Meteor. Soc., 143, 942-956, https://doi.org/10.1002/qj.2851, 2017.

Lin, Y.: Orographic effects on airflow and mesoscale weather systems over Taiwan, Terr. Atmos. Ocean, 4, 381-420, 1993.

Masson, V., Le Moigne, P., Martin, E., Faroux, S., Alias, A., Alkama, R., Belamari, S., Bardu, A., Boone, A., Bouyssel, F., Brousseau, P., Brun, E., Calvet, J.C., Carrer, D., Decharme, B., Delire, C., Donier, S., Essaouini, K., Gibelin, A. L., Giordani, H., Habets, F., Jidane, M., Kerdraon, G., Kourzeneva, E., Lafaysse, M., Lafont, S., Lebeaupin, BC., Lemonsu, A., Mahfouf, J.F., Marguinaud, P., Mokhtari, M., Morin, S., Pigeon, G., Salgado, R., Seity, Y., Taillefer, F., Tanguy, G., Tulet, P., Vincendon, B., Vionnet, V., and Voldoire, A.: The surfex v7.2 land and ocean surface platform for coupled or offline simulation of earth surface variables and fluxes, Geosci. Model Dev., 6, 929-960, https://doi.org/10.5194/gmd-6-929-2013, 2013.

Miglietta, M. and Rotunno, R.: Numerical simulations of sheared conditionally unstable flows over a mountain ridge, J. Atmos. Sci., 71, 1747-1762, 2014.

Mlawer, E. J., Taubman, S. J., Brown, P. D., Iacono, M. J., and Clough, S. A.: Radiative transfer for inhomogeneous atmospheres: RRTM, a validated correlated-k model for the longwave, J. Geophys. Res., 102, 16663-16682, 1997.

Nuissier, O., Ducrocq, V., Ricard, D., Lebeaupin, Brossier C., and Anquetin, S.: A numerical study of three catastrophic precipitating events over southern France. I: Numerical framework and synoptic ingredients, Q. J. Roy. Meteor. Soc., 134, 111-130, 2008.

Nuissier, P., Joly, B., Joly, A., Ducrocq, V., and Arbogast, P.: A statistical downscaling to identify the large-scale circulation patterns associated with heavy precipitation events over southern France, Q. J. Roy. Meteor. Soc., 137, 1812-1827, https://doi.org/10.1002/qj.866, 2011.
Pergaud, J., Masson, V., Malardel, S., and Couvreax, F.: A parameterization of dry thermals and shallow cumuli for mesoscale Numerical Weather Prediction, Bound.-Lay. Meteorol., 132, 83106, https://doi.org/10.1007/s10546-009-9388-0, 2009.

Pinty, J. P. and Jabouille, P.: A mixed-phased cloud parametrization for use in a mesoscale non-hydrostatic model: Simulations of a squall line and of orographic precipitation, in: Proc. of the Conference on Cloud Physics, Am. Meteorol. Soc, Boston, Everett, WA, USA, 17-21 August 1998, 217-220, 1998.

Ricard, D., Ducrocq, V., and Auger, L.: A climatology of the mesoscale environment associated with heavily precipitating events over a northwestern mediterranean area, J. Appl. Meteorol. Climatol., 51, 468-488, https://doi.org/10.1175/JAMC-D11-017.1, 2012.

Romero, R., Sumner, G., Ramis, C., and Genoves, A.: A classification of the atmospheric circulation patterns producing significant daily rainfall in the Spanish Mediterranean area, Int. J. Climatol., 19, 765-785, 1999.

Romero, R., Ramis, C., and Homar, V.: On the severe convective storm of 29th October 2013 in the Balearic Islands: Observational and numerical study, Q. J. Roy. Meteor. Soc., 141, 12081222, https://doi.org/10.1002/qj.2429, 2015.

Rotunno, R. and Ferretti, R.: Mechanisms of intense Alpine rainfall, J. Atmos. Sci., 58, 1732-1749, 2001.

Seity, Y., Brousseau, P., Malardel, S., Hello, G., Bernard, P., Bouttier, F., Lac, C., and Masson, V.: The AROME-France convective-scale operational model, Mon. Weather Rev., 139, 976-991, 2011.

Shu, C. W. and Osher, S.: Efficient implementation of essentially non-oscillatory shock-capturing schemes, J. Comput. Phys., 77, 439-471, 1988.

Smith, R.: The influence of mountains on the atmosphere, Adv. Geophys., 21, 87-230, 1979.

Sodemann, H., Aemisegger, F., Pfahl, S., Bitter, M., Corsmeier, U., Feuerle, T., Graf, P., Hankers, R., Hsiao, G., Schulz, H., Wieser, A., and Wernli, H.: The stable isotopic composition of water vapour above Corsica during the HyMeX SOP1 campaign: insight into vertical mixing processes from lowertropospheric survey flights, Atmos. Chem. Phys., 17, 6125-6151, https://doi.org/10.5194/acp-17-6125-2017, 2017.

Trapero, L., Bech, J., and Lorente, J.: Numerical modelling of heavy precipitation events over Eastern Pyrenees: Analysis of orographic effects, Atmos. Res., 123, 368-383, 2013a.

Trapero, L., Bech, J., Duffourg, F., Esteban, P., and Lorente, J.: Mesoscale numerical analysis of the historical November 1982 heavy precipitation event over Andorra (Eastern Pyrenees), Nat. Hazards Earth Syst. Sci., 13, 2969-2990, https://doi.org/10.5194/nhess-13-2969-2013, 2013 b.

Weckwerth, T., Parsons, D. B., Koch, S. E., Moore, J. A., LeMone, M. A., Demoz, B. B., Flamant, C., Geerts, B., Wang, J., and Feltz, W. F.: An overview of the International H2O Project (IHOP2002) and some preliminary highlight, Bull. Am. Meteorol. Soc., 85, 253-277, 2004. 